\section{(C) OPEN ACCESS}

\title{
Outcome measures in coeliac disease trials: the Tampere recommendations
}

\author{
Jonas F Ludvigsson, ${ }^{1,2}$ Carolina Ciacci, ${ }^{3}$ Peter HR Green, ${ }^{4}$ Katri Kaukinen, 5,6 \\ IIma R Korponay-Szabo, ${ }^{7,8}$ Kalle Kurppa, ${ }^{9,10}$ Joseph A Murray, ${ }^{11}$ \\ Knut Erik Aslaksen Lundin, ${ }^{12,13}$ Markku J Maki, ${ }^{14,15}$ Alina Popp, ${ }^{16,17}$ Norelle R Reilly, ${ }^{18,19}$ \\ Alfonso Rodriguez-Herrera, ${ }^{20}$ David S Sanders, ${ }^{21}$ Detlef Schuppan, ${ }^{22,23}{ }^{23}$ Sarah Sleet, ${ }^{24}$ \\ Juha Taavela, ${ }^{25}$ Kristin Voorhees, $^{26}$ Marjorie M Walker, ${ }^{27}$ Daniel A Leffler ${ }^{28}$
}

Additional material is published online only. To view, please visit the journal online (http://dx.doi.org/10.1136/ gutjnl-2017-314853).

For numbered affiliations see end of article.

Correspondence to Dr Jonas F Ludvigsson, Department of Medical Epidemiology and Biostatistics, Karolinska Institutet Stockholm 171 77, Sweden; jonasludvigsson@yahoo.com

Received 14 July 2017 Revised 19 December 2017 Accepted 8 January 2018

Published Online First

13 February 2018
Check for updates

To cite: Ludvigsson JF, Ciacci C, Green PHR, et al. Gut 2018;67:1410-1424.

\section{ABSTRACT}

Objective A gluten-free diet is the only treatment option of coeliac disease, but recently an increasing number of trials have begun to explore alternative treatment strategies. We aimed to review the literature on coeliac disease therapeutic trials and issue recommendations for outcome measures.

Design Based on a literature review of 10062 references, we (17 researchers and 2 patient representatives from 10 countries) reviewed the use and suitability of both clinical and non-clinical outcome measures. We then made expert-based recommendations for use of these outcomes in coeliac disease trials and identified areas where research is needed.

Results We comment on the use of histology, serology, clinical outcome assessment (including patient-reported outcomes), quality of life and immunological tools including gluten immunogenic peptides for trials in coeliac disease.

Conclusion Careful evaluation and reporting of outcome measures will increase transparency and comparability of coeliac disease therapeutic trials, and will benefit patients, healthcare and the pharmaceutical industry.

\section{INTRODUCTION}

Coeliac disease (CD) is an immune-mediated disease triggered by gluten exposure. ${ }^{1}$ Although characterised by small intestinal inflammation, consequences are widespread and linked to diverse manifestations that include osteoporosis, ${ }^{2}$ lymphoma, ${ }^{3}{ }^{4}$ pneumonia $^{5}$ and increased mortality. ${ }^{6}$ Symptoms vary, with some patients having diarrhoea and malabsorption (often termed 'classical CD'), others suffering from constipation, fatigue and depression (non-classical CD) and some are asymptomatic (subclinical CD). ${ }^{7}$ The global prevalence of $\mathrm{CD}$ is about $1 \%-2 \%,{ }^{89}$ but seems to be increasing. ${ }^{10} 11$

Lifelong adherence to a gluten-free diet (GFD) is the only available treatment for CD. ${ }^{1}$ For several reasons, patients find the GFD to be exceedingly burdensome, ${ }^{12}$ that is, it is socially restrictive ${ }^{13}$ and more expensive than ordinary food. ${ }^{14-16}$ Patients differ in their ability to adapt psychologically to CD. Some people have little difficulty in adopting the GFD, whereas for others, living with CD is a

\section{Significance of this study}

What is already known about this subject?

- A gluten-free diet is the only treatment option of coeliac disease, but recently an increasing number of trials have begun to explore alternative treatment strategies.

- A large number of trials of non-dietary treatments for coeliac disease are ongoing or under way.

- There is no consensus on outcome measures in coeliac disease trials.

What are the new findings?

- After an extensive literature review, 17 researchers and 2 patient representatives from 10 countries reviewed the use and suitability of histology, serology, clinical outcome assessment (including patient-reported outcomes), quality of life and immunological tools that comprised gluten immunogenic peptides for trials in coeliac disease.

- In this paper, we make expert-based recommendations for use of these outcomes in coeliac disease therapeutic trials.

How might it impact on clinical practice in the foreseeable future?

- Following the outlined recommendations of this paper, will increase transparency and comparability of coeliac disease therapeutic trials with benefit to patients, healthcare and the pharmaceutical industry.

daily struggle. ${ }^{13}$ In addition to the burden of treatment, patients with CD frequently have ongoing symptoms and mucosal healing is slow and often incomplete. For these reasons, there is a need for alternative treatments of $\mathrm{CD}$, as suggested by the intensive research efforts undertaken in different laboratories. ${ }^{17}$ Potential targets for treatment include glutenases, modified or pretreated gluten, gluten sequestrants, neutralising antibodies, inhibitors of intestinal permeability, lymphocyte blockers, including anti-interleukin-15, tissue transglutaminase (TG2) inhibitors, immune tolerance induction, exposure to hookworms and 
DQ2-blocking peptide analogues. ${ }^{17} 18$ Several of these drugs are now being tested in phase I or phase II trials, and a recent study found that novel therapies attract the interest of patients with CD more than any other disease-related topic. ${ }^{19}$

Of importance is that treatment effects are measured against robust standards. A recent systematic review ${ }^{20}$ identified six histological CD activity indices, ${ }^{21-26}$ five patient-reported outcomes (PROs) $^{27-31}$ and four indices for endoscopic CD activity ${ }^{32-35}$ that have been used for coeliac trials.

In the present paper, we have explored clinical, serological, histological and immunological outcome measures for performing clinical trials in CD, and importantly, have included the patient perspectives concerning recommendations for their use.

\section{METHODS}

\section{Task force}

Coauthors were invited by JFL and DAL with the aim to obtain a group with knowledge, experiences and interests that reflect the heterogeneity of outcome measures used in trials of CD. Most of the participating researchers were adult gastroenterologists (PHRG, CC, DSS, KKa, DS, JAM, JT, KEAL, DAL) but our group also included six paediatricians (JFL, NRR, KKu, MJM, AP, IRK-S), one pathologist (MMW), one basic scientist (AR-H) and two representatives of patient organisations (SS and KV). Members of this diverse collaboration originated from 10 countries. Most of the coauthors participated in the CD meeting organised by MJM in Tampere, Finland on 24-25 November 2016 (which provides the motivation for the subtitle of this paper).

\section{Literature review}

Coauthors were divided into seven teams of three to four individuals who jointly reviewed five domains: serology, histology, immunology, PROs and other outcome measures. The Karolinska Institutet library carried out literature searches for relevant papers up until 1 December 2016 (see online supplementary appendix). This search yielded 10062 references. After reviewing titles and abstracts for these 10062 references (online supplementary appendix), there remained 941 publications that were considered potentially relevant for this review and subsequently read in detail.

In this paper, we issued a number of recommendations. Where appropriate these were graded according to the method suggested by the Oxford Centre or Evidence-based Medicine, ${ }^{36}$ where grade A evidence represents the highest level of evidence and grade D the lower available evidence (generally based on the opinion of experts but with no preceding randomised trials, cohort or case-control studies). The appendix contains a detailed description of grade A-D. All recommendations were subject to a post hoc voting on a five-level scale (strongly disagree, disagree, not agree or disagree, agree and strongly agree).

\section{Manuscript draft}

JFL wrote the first draft of the paper. The text was then extensively revised by the coauthors. JFL and DAL supervised these revisions, but all authors contributed and agreed on the conclusions and the final wording of the paper.

This is a series of expert-based recommendations and did not meet the requirements of a formal systematic review (eg, the Preferred Reporting Items for Systematic Reviews and Meta-Analyses statement ${ }^{37}$ ). We aimed to highlight the state-ofthe-art of designing intervention trials in CD.

\section{RESULTS}

\section{Histology}

Clinicopathological correlation is key to the diagnosis of CD in adults and children. In adults, confirmation of the diagnosis by duodenal biopsy is the gold standard. ${ }^{78} 39$ In Europe, a 'biopsy-sparing' protocol (with defined limitations for use) has been adopted for symptomatic children defined by an antiTG2 titre $\geq 10$ times the upper limit of normal, positive endomysial antibody (EMA) on a second blood draw and positivity for human leucocyte antigen haplotypes HLA-DQ2 and/or HLA-DQ8. ${ }^{40}$ To evaluate effective treatment for CD, quantitative histological assessment (morphometry) outperforms qualitative histology (eg, the Marsh score) in a trial setting. ${ }^{20}$ In clinical trials, optimised biopsy protocols should be followed for assessment of mucosal damage or healing.

Well-known classifications in histological assessment are described by Marsh and modified by Oberhuber ${ }^{738}$ and Corazza and Villanacci. ${ }^{41}$ Although grouped classifications are practical in clinical work, recent studies have shown imperfect reproducibility and reliability. ${ }^{26} 42$

Recently published recommendations for biopsy diagnosis of $\mathrm{CD}$ in adult patients for the number of biopsies and sites are available ${ }^{3839}$ with optimal laboratory processing alongside structured reports to include validated morphometric analysis. ${ }^{26} 38$

It is recommended to take at least five duodenal biopsies, one or two from the duodenal bulb (D1) and four from the second part of the duodenum (D2). ${ }^{38} 39$ These biopsies should be taken across circular folds to avoid a crushing artefact. ${ }^{43}$ Endoscopists should take one biopsy specimen per pass of the forceps in that a single-biopsy technique improves the yield of well-oriented duodenal biopsy specimens. ${ }^{44}$ Biopsies from D1 and D2 should be reviewed separately by a pathologist. ${ }^{45}$

When processed in the laboratory, biopsies should be oriented correctly and sectioned at three levels. In trial settings it is appropriate to always count intraepithelial lymphocytes (IELs) and state the number present/100 enterocytes (normal counts are $\leq 25 / 100$ enterocytes). ${ }^{726394546}$ IELs can be counted in H\&E stained sections; however, immunohistochemistry with CD3 is preferred by some pathologists. ${ }^{26} 47$ Frozen tissue specimens have been used to evaluate T-cell receptor gamma delta positive $(\gamma \delta+) \mathrm{T}$ cells, ${ }^{48}$ but new antibodies for use on paraffin-embedded specimens are now available. ${ }^{49} 50$ Identification of a high density of $\gamma \delta+$ T cells is relatively specific for CD and can be useful when histological diagnosis remains equivocal. ${ }^{48} 49$

Immunohistochemistry to show deposited immunoglobulin A targeting TG2 in the small bowel mucosa is accurate in the detection of CD if patients are on a gluten-containing diet. ${ }^{51}$ These deposits have had $100 \%$ sensitivity $^{52}$ and a mean specificity of $94 \%{ }^{53}$ for CD. The deposits have been used in several gluten challenge studies to measure gluten reactivity. ${ }^{52}$ This technique requires the use of frozen tissue. The use of frozen tissue in clinical trials has shown variable results, which mirrored serum TG2 antibodies with increased deposits. ${ }^{54}$

Morphometry, in which continuous variables such as the villous height-to-crypt depth ratio and IEL density are measured separately, overcomes certain problems encountered when using grouped classifications. ${ }^{2655}$ Of note, a threshold change of 0.4 represents a measurable and likely clinically relevant difference between villous height:crypt depth ratio measurements. A villous height:crypt depth ratio of $<2$ is indicative of atrophy, active disease. Patients with treated CD have values above 3. Similarly, $\geq 30 \%$ change in T-cell IEL densities is considered clinically significant. ${ }^{26}$ 
Importantly, morphometry, which has produced excellent reproducibility and reliability, ${ }^{26}$ has a significant role in clinical trials in which reliable and accurate measurements are a requirement. ${ }^{56}$ Whichever classification is used, two blinded observers should read the histology to ensure reliability in clinical trials. ${ }^{26}$ It should be noted that CD can be patchy and there is some intrasubject and even intrabiopsy variability in villous architecture and lymphocyte numbers contributing to sampling error and difficulties in interpretation. Given this, and that only a small proportion of the proximal small intestinal mucosa is evaluated by conventional biopsy review, new tools are needed for assessment of mucosal health. The optimal timing of biopsy to evaluate healing should be a clinicopathological decision dependent on treatment offered and taking into account possible sampling errors by following protocols for biopsy sites.

In CD, there may be concurrent upper GI pathologies (eg, Helicobacter pylori infection, ${ }^{57} 58$ lymphocytic gastritis ${ }^{59}$ and eosinophilic oesophagitis/oesophageal eosinophilia ${ }^{60}$ ) that should be assessed at initial endoscopy if clinical history is suggestive, and if present, reassessed post-treatment because these may contribute to ongoing symptoms not related to small intestinal damage.

Patients included in studies for CD therapy must have had an initial robust diagnosis. Occasionally, patients will have been diagnosed without histological confirmation. ${ }^{61}$ These patients should not be included in gluten challenge studies but instead included in trials of active CD treatment. Patients with a study entry biopsy confirming villous atrophy (VA) and a record of positive serology and permissive HLA status should be eligible for treatment studies in CD.

As per the current European Society for Paediatric Gastroenterology Hepatology and Nutrition guidelines, ${ }^{40}$ we are reluctant to suggest timelines for control biopsies for children, although a recent paper found that mucosal healing may not be as complete as previously assumed. ${ }^{62}$ For now, follow-up biopsy in children should be dictated by clinical needs.

Table 1 summarises changes in mucosal histopathology, serology and symptoms in clinical trials with gluten challenge.

Recommendations: Histology is an essential outcome measure in any trials of CD treatment (grade B). Histology should be performed both before and at the end of the trial when healing or histological relapse is the primary outcome measure (grade B). In a gluten challenge study, successful treatment may be characterised as no change, or, in a treatment study, as histological improvement by a significant increase in the villous height:crypt ratio ( $>0.4$ being considered relevant) and/or a $\geq 30 \%$ change in IEL densities (grade D). Additionally, histology may be useful as a criterion for study inclusion in which participants in gluten challenge studies should have a high villous height:crypt depth of $>2-3$ and participants in treatment trials should have a decreased villous height:crypt depth ratio of $<2-3$ (grade D). Histological evaluation should follow a priori histology protocols using quantitative measures.

Vote: agree: 7; strongly agree: 12.

\section{Serology}

Serology is a cornerstone in the diagnostic workup for CD. ${ }^{38} 396364$ IgA auto-antibodies to TG2 and IgG antibodies to deamidated gliadin peptides (DGPs) are central diagnostic tests for active CD. In IgA-sufficient patients, IgA-anti-TG2 is the most predictive and reproducible single test, although IgA EMA performs similarly well in some expert laboratories and is often used as a confirmatory test. IgG anti-DGP displays similar sensitivity as IgA anti-TG2 but has lower specificity. Selection of optimal serological tests is mandatory because not all commercial assays perform equally well. ${ }^{65}{ }^{66}$ Importantly, calculation of results and thus numerical values for the same samples ${ }^{59}$ also may differ and only tests with a multipoint calibration curve give values proportional to serum antibody concentration. ${ }^{40}$ Differences in assays can make interpretation in and comparisons between clinical trials difficult. This difficulty is in part due to different epitopes that are detected by different tests, different calibration or to antibodies with lower avidity and specificity. ${ }^{67-69}$ Thus, an important shortcoming when using serology to evaluate the outcome of gluten challenge is the wide range of response. When the UK National External Quality Assessment consortium tested the same positive samples in 14 commercial anti-TG2 assays, large differences in antibody levels were found, consistent with substantial variability for antibodies used in the diagnosis of $\mathrm{CD} .^{65}$

Overall, a correlation exists between IgA-anti-TG2 antibody titres and the severity of mucosal damage by histology, as well as the histological outcome on a GFD. ${ }^{70-73}$ Yet, a recent meta-analysis found that serum TG2 and EMA often underestimate the degree of VA. ${ }^{74}$ Antibody titres below diagnostic cut-offs, thus, do not predict a normal or near-normal (Marsh I) histology. The one caveat is that biopsies usually sample a short segment of the (descending) duodenum, whereas active CD can affect large portions of the small intestine that occasionally extend down to the ileum. ${ }^{75}$ Therefore, a patient may be in clinical and serological remission with residual inflammation in the proximal duodenum but which is quantitatively much less extensive than before. $^{74}$ Thus, in one of the largest studies to date, ${ }^{76}$ IgA antiTG2 failed to detect 44\% of persistent VA (Marsh III) in patients with CD on a GFD for $>1$ year.

Normal serology is generally required for entry into a gluten challenge study to ensure that participants do not have severe VA prior to gluten challenge. Conversely, serology above diagnostic cut-offs has not been used as an inclusion criterion for treatment studies in non-responsive CD because many people with a normal serology will still have VA and ongoing symptoms. ${ }^{74}$ Participants with elevated serologic tests may respond better to some therapies. While this remains to be confirmed, stratification by CD antibody levels at study entry should be considered.

In clinical trials, serology may be used in assessing change during gluten challenge or to monitor longer treatment studies. The antibody response to gluten challenge depends on four factors: duration of the previous GFD, daily amount of ingested gluten, ${ }^{54}$ duration of gluten intake and individual factors.

Patients with CD may tolerate different levels of gluten exposure. When low (1-3g/day) or moderate (3-5g/day) amounts of gluten were administered to 25 Finnish patients with CD in remission for 12 weeks, only $67 \%$ of the patients with CD showed signs of mucosal inflammation and $43 \%$ developed positive IgA-anti-TG2 antibodies. ${ }^{54}$ However, in a US study of 20 adult patients with $\mathrm{CD}$ in remission challenged with 3 or $7.5 \mathrm{~g}$ gluten/day for 2 weeks, Marsh III histology developed in $68 \%$ of the patients with CD, whereas anti-TG2 and anti-DGP antibodies increased in only 25\% for anti-TG2\% and 30\% for anti-DGP. Remarkably, positivity for both antibodies increased to $55 \%$ and $45 \% 2$ weeks after the end of gluten challenge. ${ }^{77}$ A recent study from Norway showed even lower proportion of patients responding serologically after 2 weeks. ${ }^{78}$ Therefore, the histology at week 2 and serology at week 4 combined showed a gluten response in nearly $90 \%$, with no difference between both doses. ${ }^{77}$ Notably, some rare patients who had been on a GFD for years may develop a tolerance to gluten ingestion that may last 


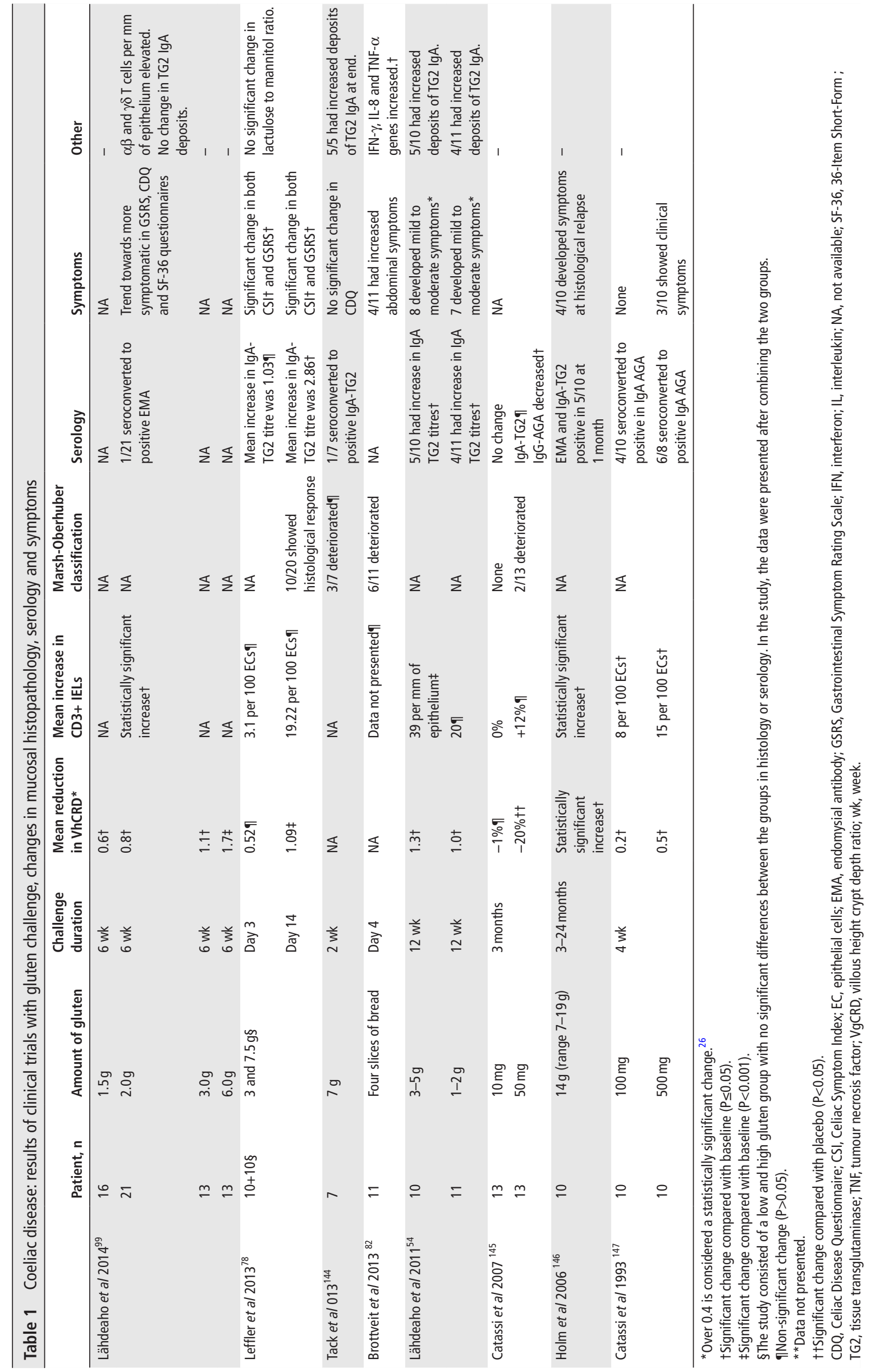


for several years. ${ }^{79}$ Overall, high serologic titres, or significant increases in serologic titres, are predictive of VA, but substantial mucosal changes may occur without a significant change in serology.

It is important to note that the serological tests were developed for the diagnosis of CD. Currently, the Food and Drug Administration (FDA) have only cleared use of coeliac serologies as an aid for diagnosis of patients with suspected CD. ${ }^{80}$ This restriction limits how serologies can be used in regulatory trials, although they are routinely used for monitoring in clinical practice. To date, no manufacturer has submitted a claim for use of serological tests for disease monitoring and the FDA is only able 'to review submitted claims'. ${ }^{80}$ Nonetheless, well validated IgA anti-TG2 and IgG anti-DGP tests will be important assets to clinical studies by helping to monitor CD activity during short and especially longer duration gluten challenge trials. Their further validation in ongoing trials may lead to FDA approval as secondary or combined (with histology or symptoms) primary end points in phase II and III clinical studies (table 1).

Recommendations: Although serology is not approved for use as a primary pivotal clinical trial outcome by the FDA, IgA TG2 and IgG DGP should, at a minimum, be measured at study entry and at completion in trials of CD (grade B). For entry into a gluten challenge study, participants should have nearnormal titres, whereas for treatment studies, titres may be either elevated or normal, with stratification by serologic titre at study entry possibly as an a priori analysis (grade B). Choice of assay should be made with care and attention be paid to dynamic range, especially around or below the cut-off for normal ranges. Preferably, an assay with a calibration curve should be applied. Although cut-off ranges for diagnosis may not be optimal for monitoring response or predicting VA, any significant increase during a trial suggests increasing CD activity and may be used as a key outcome in some studies.

Vote: agree: 2; strongly agree: 17.

\section{Immunological tools to measure treatment outcomes}

Known innate, and particularly adaptive, immune mechanisms in $\mathrm{CD}$, are prime candidates to measure treatment outcomes with and without gluten challenge. These may be non-invasive blood tests, duodenal biopsies with histological assessment by immunocytochemistry, gene expression signatures or in vitro culture.

With in vivo gluten challenge, there is rapid immune activation in the duodenum. ${ }^{81-83}$ One study found that interferon (IFN)- $\gamma$ was increased both at baseline and with gluten challenge and for this reason does not appear to be a useful measure of disease activity. ${ }^{82}$ A whole-blood IFN- $\gamma$ release assay is a much more promising measure for identifying immune responsiveness to gluten. $^{8485}$

Treated patients with CD and healthy individuals show highly variable differences in serum cytokines and chemokine levels. ${ }^{86}$ Gluten challenge, however, induces a wave of cytokine release. ${ }^{78}$

In the lamina propria of the duodenal mucosa gluten peptides are taken up by dendritic (antigen-presenting) cells with surface HLA-DQ2 or DQ8 MHC molecules to stimulate gluten peptide reactive CD4+ Tcells. ${ }^{87-90}$ On day 6 of postgluten challenge an increase of active disease gluten responsive T cells was seen in peripheral blood. ${ }^{91} 92$ These T cells can be demonstrated in Enzyme-Linked ImmunoSpot (ELISPOT) assays of cytokines when rechallenged with gluten ex vivo. Overall, $80 \%-90 \%$ of treated patients with CD in remission will show a positive response on challenge. T cells can also be demonstrated by binding to HLA-DQ-gliadin peptide tetramers, a construct consisting of multimers of HLA-DQ2 or HLA-DQ8 molecules bound to a gluten peptide and a reporter molecule giving a signal in flow cytometry. ${ }^{93}{ }^{94}$ Here, also 80\%-90\% of challenged patients with $\mathrm{CD}$ in remission will have a positive test. ${ }^{95}$ However, both the ELISPOT and the HLA-DQ2gluten tetramer tests are confounded by large interindividual differences and small number of studied patients. Recently, the HLA-DQ2-gluten tetramer technology has demonstrated disease-specific $\mathrm{T}$ cells in the peripheral blood even without a gluten challenge. ${ }^{96}$ This, together with the demonstration of restricted T-cell receptors, ${ }^{97}$ may lead to new outcome measurements.

Serum IgA anti-TG2 antibody levels as biomarkers of disease activity seem to be a useful tool (see the 'Serology' section). Peripheral blood B cells may also prove to be a potential source of future biomarkers. ${ }^{98}$ The local mucosal production of antibodies targeting extracellular TG2 in vivo has shown potential in diagnosis, ${ }^{51}$ but was not informative beyond standard histology in a clinical drug trial with gluten challenge. ${ }^{99}$

Recommendations: Although several immunological markers are under development as potential outcome measures, they have not been validated for therapeutic trials. At this point, they should only be used as exploratory outcomes in phase II and III clinical trials (grade D).

Vote: agree: 2; strongly agree: 17.

\section{Gluten immunogenic peptides as a compliance measure}

Symptom monitoring, serology and histology are at best indirect measures of GFD adherence with imperfect overall accuracy. ${ }^{100}$ Similarly, diet questionnaires are poor predictors of gluten exposure. $^{100}$

Gluten immunogenic peptides (GIPs), including the 33-mer peptide from $\square$ 2-gliadin, are resistant to GI digestion. ${ }^{101} 102$ Because of this resistance, GIP can be detected in faeces or urine and thus provides direct evidence and likely quantitation of intake. ${ }^{103}$ A clinical trial examined correlations between faecal GIPs and traditional methods to monitoring the GFD. ${ }^{104}$ The majority $(85.7 \%)$ of children with CD under 3 years of age had faeces negative for GIPs. Among those aged $\geq 13$ years, faecal positivity for GIPs rose to $39.2 \%$. More males were positive for GIPs in faeces compared with females $(60 \%$ vs $31.5 \%$, $\mathrm{P}=0.034)$. Serum IgA anti-TG2 was found negative in 40 of the 56 patients with GIP-positive stools. Today's data suggest that GIP testing may be superior to questionnaires or anti-TG2 antibodies. ${ }^{104}$ Furthermore, a strong correlation has been demonstrated between the absence of GIPs in urine and healing of the intestinal epithelium. ${ }^{105}$ The first therapeutic clinical trials using the technology are ongoing (NCT02637141, NCT02633020). Whereas coeliac trial investigators and sponsors had to previously guess whether patients were consuming gluten or adhering to the GFD, this technology decreases the guesswork with data to accurately interpret results and outliers. The assay could possibly be developed for quantitative detection of the rate of glutamine residue deamidation in trials aiming at interfering with transglutaminase activity. ${ }^{106}$

Recommendations: GIP testing is a promising tool for evaluating and selecting patients for clinical trials in CD aimed at reducing toxicity related to gluten exposure (grade D). Hence, it should be considered in future trials, especially for trials in non-responsive $\mathrm{CD}$ for therapies that are designed to prevent symptoms because of inadvertent gluten exposure (grade D).

Vote: agree: 4; strongly agree: 15 . 


\section{Clinical trial end points}

The ideal clinical trial end point should be clearly linked to an outcome important to patients, reliable, responsive to treatment, clinically or physiologically proximal to the outcome of interest and efficient and scalable for use in diverse clinical trial settings. Although in some areas biomarkers may be used as primary outcomes in clinical trials, these rarely have sufficient data for regulatory acceptance. ${ }^{107}$ In contrast, clinical outcome assessments can be more easily linked to patient well-being: clinical outcome assessments are grouped into PROs, clinician-reported outcomes, observer-related outcomes and performance outcomes. Clinician-reported outcomes, such as physician global assessment, are of limited value as they do not directly assess patient status and generally do not correlate well with PROs. Observer-related outcomes can be vital in specific populations, such as young children, where direct response is not possible. Symptom-focused PROs are the main clinical outcome assessment in use in CD and in gastroenterology overall and are the focus of this section, although other clinical outcomes will also be discussed.

From a clinical/practical perspective, PROs can be helpful to monitor patient status and target quality improvement initiatives. ${ }^{108}$ A growing number of digital devices allow patients to track and transmit symptom data to their physician; however, for these to be useful for practising clinicians, PROs must be easy to administer and interpret, as well as to allow feasible clinical interventions. ${ }^{108}$ In research and clinical trials, the key features of PROs that should be considered are high responsiveness to change and low participant burden.

For patients, the ideal PRO must focus on the symptoms or disease attributes most meaningful to them while again minimising time and complexity of use. In CD, this is particularly important given the significant impact on emotional, mental and social well-being due to the constant vigilance required by the GFD. Finally, from a regulatory standpoint, the ability to use a PRO in a pivotal clinical trial to support a labelling claim depends on whether its characteristics (eg, concept being measured, content validity, conceptual framework, intended population, format, scoring) are satisfactory and clearly documented in a regulatory dossier, which is now available for only a few PROs. ${ }^{109}$

Presently available PROs frequently used in CD or developed for CD include the Gastrointestinal Symptom Rating Scale (GSRS), ${ }^{110} 111$ the Celiac Symptom Index (CSI), ${ }^{31}$ the Celiac Disease PRO (CeD-PRO), ${ }^{27}$ the Celiac Disease Symptom Diary $(\mathrm{CDSD})^{112}$ and the Celiac Disease Assessment Questionnaire (CDAQ). ${ }^{113}$ Of these, the GSRS has been used most frequently, ranging from natural history to the effects of the GFD to clinical trials of novel therapeutics. ${ }^{110}{ }^{114-116}$ The GSRS was developed originally for peptic disease and irritable bowel syndrome, ${ }^{117}$ but because the symptoms of many GI disorders overlap, it has proven useful for a variety of GI disorders, including $\mathrm{CD} .{ }^{118}$ However, it is not optimised for CD and would not be appropriate for use in pivotal trials. Conversely, the CSI was developed specifically for $\mathrm{CD}$ and has been used in many cross-sectional and interventional studies. ${ }^{119}{ }^{120}$ However, its development was completed before the 2009 FDA guidance ${ }^{109}$ and thus the CSI lacks much of the documentation necessary for regulatory clearance. Conversely, both the CDSD and the CeD-PRO were developed specifically for regulatory approval of $C D$ therapeutics and are preferred instruments for this purpose.

The CDAQ was recently developed and assesses a variety of domains: symptoms, dietary burden, worry, stigma, and social isolation. ${ }^{121}$ As such, it is a hybrid of the health-related quality of life (HRQoL) tools discussed below and a symptom PRO. It is unclear if this instrument were developed and documented in line with regulatory guidance: in the CDAQ both constipation and diarrhoea are evaluated in a single combined question that may make changes in these important symptoms difficult to assess. However, the incorporation of these or similar HRQoL domains related to disease burden is critical in ensuring that outcomes are relevant and meaningful to patients.

Across these instruments, there is significant overlap, which is expected given the limited number of GI symptoms in general (table 2): common to all the PROs are diarrhoea, abdominal pain, bloating, and nausea. It should be acknowledged that while PROs in general may be developed and tested in specific diseases, they will not discriminate between diseases and therefore scores

Table 2 Symptoms assessed across PROs in CD

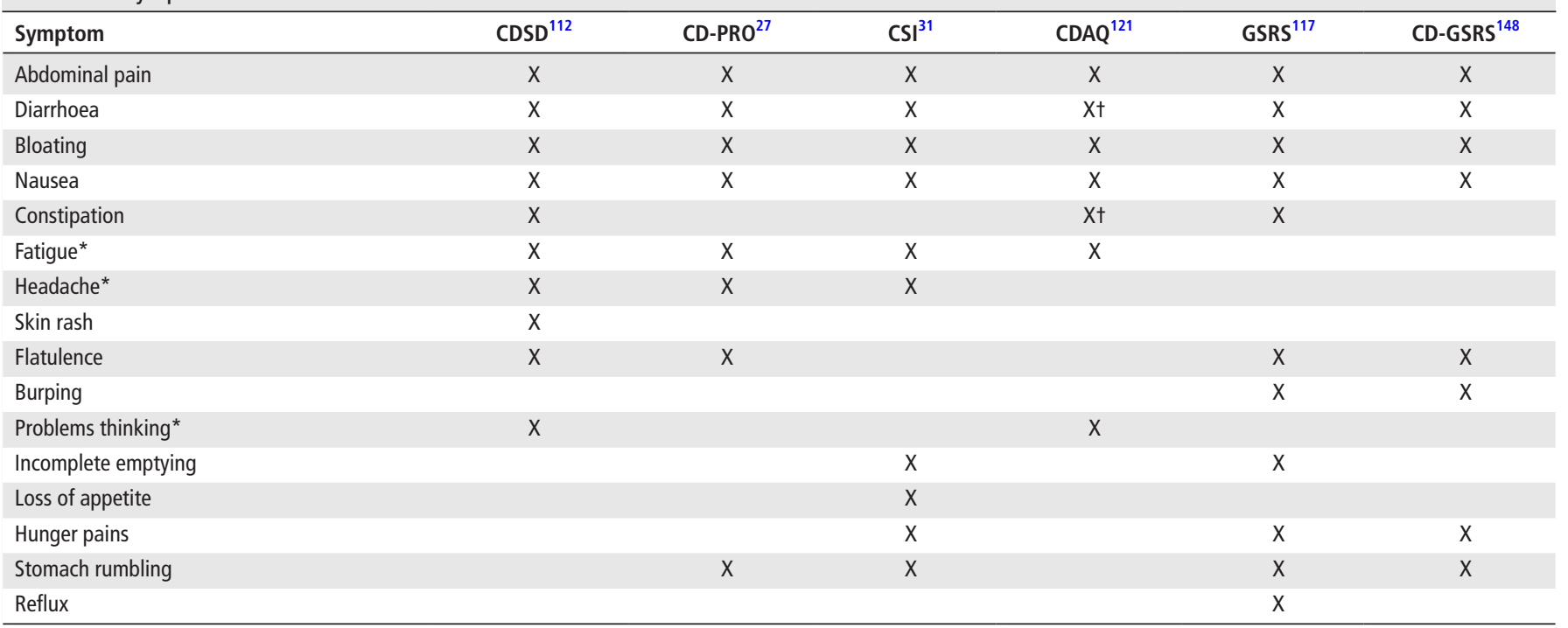

${ }^{*}$ Removed from final PRO as per the Food and Drug Administration recommendations.

†Assessed in a single domain.

CD, coeliac disease; CDAQ, Celiac Disease Assessment Questionnaire; CDSD, Celiac Disease Symptom Diary; CSI, Celiac Symptom Index; GSRS, Gastrointestinal Symptom Rating Scale; PRO, patient-reported outcome. 
for patients with different GI disorders will overlap. ${ }^{122}$ There is also a poor correlation between symptoms, histology, and serology ${ }^{80} 123$ that is due in part to a different time to response after gluten exposure or coexisting symptoms due to irritable bowel syndrome or undetected food allergy. ${ }^{124}$ Thus, it is also clear from recent clinical trials that many symptomatic patients have no histological or serologic evidence of active CD and many patients with significant enteropathy have few or no symptoms. $^{78} 80112116125$ Meanwhile complete recovery of small intestinal lesions is very rare in adult CD patients despite symptom disappearance. ${ }^{126}$

In addition, PRO use in CD can be challenging because of symptom heterogeneity (eg, asymptomatic or paucisymptomatic patients) and variable extraintestinal manifestations, for which no PROs are available. In contrast to disorders such as chronic constipation or headache in which one symptom defines the condition, symptoms in CD can vary substantially between individuals and hence careful attention to PRO use is mandatory. Moreover, responsiveness to change of non-symptom-based dimensions in PROs can vary significantly and must be carefully assessed in relation to the intervention under investigation. For example, measures of quality of life (QoL) may be less amenable to change if the intervention does not reduce dietary burden, social isolation and stigma, which are closely linked to managing the GFD. Comparing overall PRO mean scores at baseline and postintervention may dilute the treatment effect if not all domains change or if changes cancel out each other (eg, diarrhoea improves but results in constipation by disrupting bowel movements). Another option is to compare the means only in prespecified domains (eg, include diarrhoea but not constipation). However, this approach may result in a highly selected population that is not representative. A more sophisticated approach is to limit primary assessment of the effect of intervention to the symptoms most bothersome to a specific patient and then to include all individuals with bothersome symptoms in the final PRO assessment. Even with this approach, for treatment trials, only patients with symptoms measured by the primary PRO outcome can be enrolled. Given the heterogeneity of $\mathrm{CD}$, it is likely that sequential trials will need to be performed with different outcomes in order to understand the utility of a particular therapy. For example, a therapy found to be useful in improving GI symptoms in CD could be assessed in a later trial assessing itch in patients with dermatitis herpetiformis.

Particularly noteworthy is that while great progress has been made in PROs in CD, there is limited experience using the more recent PROs in languages other than English and none has been validated for use in paediatric populations. Although it is expected that the PROs developed for CD in adults will be applicable for paediatric populations, this still requires validation. For example, young children and teens may define improved QoL differently because of unique challenges in school, social settings and peer relationships. Furthermore, improvement in extraintestinal symptoms, including behavioural changes, may be more relevant among paediatric patients. Development of formats suitable for caregivers of children unable to independently complete the questionnaires must also be advanced. Development of responder definitions and minimal clinically important change are additional areas requiring development to realise the potential of CD PROs in clinical research.

Given that the relative SD of histology is substantially smaller than that of symptoms, for a study where several hundred patients are needed to adequately detect differences in symptoms, fewer patients may be needed for the histology end point. Under such circumstances, researchers may choose to perform histology on a random sample of study participants provided that they have sufficient study power for the histology end point.

Recommendations: Clinical end points must be included in trials of CD and generally PROs should be a primary outcome in studies of treatment of active CD, generally late phase II and III (grade D). Thus far, there is insufficient evidence to recommend one specific scale, although the CDSD and the CeD-PRO appear most likely to meet regulatory requirements (grade D). Given the heterogeneity of symptoms in patients with $C D$, it is adequate to limit analyses to certain domains, either in the study overall or to allow for participant-specific symptom assessments. However, such decisions should be made at study entry and rigorously documented.

Vote: agree: 3 ; strongly agree: 16 .

\section{Health-related quality of life assessment}

Clinical trials must also consider the ongoing psychological burden of CD to better understand the outcomes. Many studies in different settings suggest that $\mathrm{CD}$ has a considerable impact on HRQoL. ${ }^{12}{ }^{127}$ In untreated CD, GI symptoms and extraintestinal issues, such as isolated anaemia, fatigue and malaise, may be responsible for reduced HRQoL. ${ }^{128}$ In general, the treatment of CD results in significant improvement in the HRQoL of symptomatic patients. ${ }^{129}$ Even in patients with silent or asymptomatic screening-detected $\mathrm{CD}$, improvement in both symptoms and HRQoL has been shown in numerous studies. ${ }^{116} 130-132$

Impairment in HRQoL may also contribute to and be impacted by psychological disorders (eg, anxiety and depression) seen in patients with CD. ${ }^{12} 133$ Whereas anxiety generally improves after diagnosis and treatment $\mathrm{CD}$, depression may exist before and persist after diagnosis. ${ }^{134}$ Moreover, anxiety and depression alone or through their impact on HRQoL can impair dietary compliance. ${ }^{12} 135$ The interaction between mood disorders, GFD adherence and HRQoL is incompletely understood and should be addressed in future trials. Additionally, the burden of a GFD may lead to ongoing HRQoL impairment despite symptom relief and improved physical well-being after dietary intervention. ${ }^{13} 19$

Because of small numbers of studies and variations in study designs, populations and HRQoL measures, we lack a complete understanding of degrees and drivers of HRQoL in individuals with untreated and treated CD. There are also few studies about the effect of CD treatment in the outcome of depression and anxiety. Therefore, further studies are required if we wish to know more about this specific aspect of CD.

Although HRQoL is generally not accepted by regulatory agencies as a primary outcome in pivotal trials, this is a key outcome for both patients and clinicians and may determine whether a therapy succeeds or fails. Arguably, a main goal of therapeutics in $\mathrm{CD}$, in addition to histological and symptom improvement, is to improve HRQoL. Indeed, it is probable that some patients in histological and symptomatic remission could have a significant HRQoL benefit from pharmacological therapy owing to a reduction in burden of the GFD and anxiety regarding potential exposures. There are several HRQoL scales that have been specifically developed for or used in CD (table 3).

Recommendations: HRQoL in CD is complex and multidimensional and may be a more relevant concern to patients than specific symptoms. In any trial aiming to improve CD control (as opposed to gluten challenge studies that aim to prevent worsening), measurement of HRQoL should be considered a critical end point that may help to determine the overall value of a therapy or intervention to both patients and payors (grade D).

Vote: agree: 4; strongly agree: 15 . 
Table 3 Quality of life instruments relevant to coeliac disease

\begin{tabular}{|c|c|c|c|}
\hline \multicolumn{4}{|l|}{ Adult instruments } \\
\hline Instrument & Author & Participants & Instrument description \\
\hline \multicolumn{4}{|l|}{ Generic } \\
\hline Zung Self Rating Depression Scale $e^{149}$ & Ciacci $2003^{150}$ & $581 C D$ & 20-Item self-report, 4-point Likert scale. Assesses four characteristics of depression. \\
\hline $\begin{array}{l}\text { Gastrointestinal Quality of Life } \\
\text { Index }\end{array}$ & Casellas $2008^{152}$ & $\begin{array}{l}340 \text { CD }-177 \text { untreated vs } \\
163 \text { on GFD }\end{array}$ & $\begin{array}{l}\text { 36-Item self-report, 4-point Likert scale. Assesses five domains: symptoms, physical function, emotional } \\
\text { function, social function and medical function. }\end{array}$ \\
\hline \multirow[t]{2}{*}{ COPE (brief) $)^{153}$} & Smith $2011^{154}$ & $156 C D$ & \multirow[t]{2}{*}{ 28-Item self-report, 4-point Likert scale. Measures 14 coping responses. } \\
\hline & Sainsbury $2013^{155}$ & $189 \mathrm{CD}$ & \\
\hline \multirow[t]{5}{*}{ EuroQol-5D 156} & Casellas $2008^{152}$ & $340 C D$ & \multirow{5}{*}{$\begin{array}{l}\text { 5-Item self-report, 5-point Likert scale plus a general health rating (scored on a } 20 \mathrm{~cm} \text { visual analogue scale). } \\
\text { Measures five dimensions: mobility, self-care, daily activities, pain/discomfort and anxiety/depression. }\end{array}$} \\
\hline & Grey $2010^{157}$ & $783 C D$ & \\
\hline & Norström $2011^{158}$ & $1031 \mathrm{CD}$ & \\
\hline & Casellas $2015^{159}$ & $366 \mathrm{CD}$ on $\mathrm{GFD}>1$ year & \\
\hline & $\begin{array}{l}\text { Ramirez-Cervantes } \\
2015^{160}\end{array}$ & $80 \mathrm{CD}$ on $\mathrm{GFD} \geq 6$ months & \\
\hline \multirow[t]{3}{*}{ Beck Depression Inventory ${ }^{161}$} & Borghini $2016^{162}$ & $\begin{array}{l}210 \text { CD (70 untreated vs } 70 \\
\text { on GFD } 6-12 \text { months vs } 70 \\
\text { on GFD }>12 \text { months) }\end{array}$ & \multirow[t]{3}{*}{$\begin{array}{l}\text { 21-Item self-report, 4-point Likert scale. Evaluates } 21 \text { symptoms of depression, including emotions, behavioura } \\
\text { changes and somatic symptoms. }\end{array}$} \\
\hline & Nachman $2009^{128}$ & 132 Newly diagnosed CD & \\
\hline & Nachman $2010^{163}$ & 53 Newly diagnosed CD & \\
\hline \multirow{11}{*}{$\begin{array}{l}\text { Psychological General Well-Being } \\
\text { Index }\end{array}$} & Ford $2012^{165}$ & $288 C D$ & \multirow{11}{*}{$\begin{array}{l}\text { 22-Item self-report, 6-point Likert scale. Includes six dimensions: anxiety, depressed mood, positive well-being, } \\
\text { self-control, general health and vitality. }\end{array}$} \\
\hline & Smith $2011^{154}$ & $156 C D$ & \\
\hline & Mustalahti $2002^{131}$ & $\begin{array}{l}19 \text { screen-detected CD vs } 21 \\
\text { symptom-detected CD }\end{array}$ & \\
\hline & Mahadev $2016^{127}$ & $\begin{array}{l}211 \text { (71 screen-detected CD } \\
\text { vs } 140 \text { symptom-detected } \\
\text { CD) }\end{array}$ & \\
\hline & Borghini $2016^{162}$ & $\begin{array}{l}210 \mathrm{CD} \text { (70 untreated vs } 70 \\
\text { on GFD } 6-12 \text { months vs } 70 \\
\text { on GFD }>12 \text { months) }\end{array}$ & \\
\hline & Paavola $2011^{130}$ & $\begin{array}{l}466 \mathrm{CD} \text { (96 screen detected } \\
\text { CD vs } 370 \text { symptom- } \\
\text { detected CD vs } 110 \text { non-CD } \\
\text { controls) }\end{array}$ & \\
\hline & Peräaho $2004^{166}$ & $39 \mathrm{CD}$ & \\
\hline & Viljamaa $2005^{167}$ & $\begin{array}{l}98 \mathrm{CD}(54 \text { screen-detected } \\
\text { CD vs } 44 \text { symptom-detected } \\
\text { CD) }\end{array}$ & \\
\hline & Ukkola $2011^{132}$ & $698 C D$ & \\
\hline & Smith $2011^{154}$ & 156 & \\
\hline & Paarlahti $2013^{168}$ & $596 C D$ & \\
\hline \multirow{5}{*}{$\begin{array}{l}\text { Hospital Anxiety and Depression } \\
\text { Scale }^{169}\end{array}$} & Häuser $2007^{170}$ & $516 C D$ & \multirow[t]{5}{*}{ 14-Item self-report, 4-point Likert scale. Seven items pertain to anxiety and seven to depression. } \\
\hline & Häuser $2006^{171}$ & $446 C D$ & \\
\hline & Barratt $2011^{172}$ & $225 C D$ & \\
\hline & Barratt $2011^{173}$ & $225 C D$ & \\
\hline & $\begin{array}{l}\text { Ramirez-Cervantes } \\
2015^{160}\end{array}$ & $80 \mathrm{CD}$ on $\mathrm{GFD} \geq 6$ months & \\
\hline \multirow{15}{*}{$\begin{array}{l}\text { The Short-Form 36-Item QoL } \\
\text { measure }^{174}\end{array}$} & Bakker $2013^{175}$ & $57 \mathrm{CD}+\mathrm{T} 1 \mathrm{D}$ & \multirow{15}{*}{$\begin{array}{l}\text { 36- Item self-report, 3-point, 5-point and 6-point Likert scales as well as binary (yes/no) response items. } \\
\text { Measures eight domains: physical functioning, role limitations due to physical health, role limitations due to } \\
\text { emotional problems, energy/fatigue, emotional well-being, social functioning, pain and general health. }\end{array}$} \\
\hline & Usai $2002^{176}$ & $58 \mathrm{CD}$ & \\
\hline & Usai $2007^{177}$ & $129 C D$ & \\
\hline & Barratt $2011^{172}$ & $225 C D$ & \\
\hline & Barratt $2011^{173}$ & $225 C D$ & \\
\hline & Hallert $1998^{115}$ & $89 C D$ & \\
\hline & Viljamaa $2005^{167}$ & $98 C D$ & \\
\hline & Johnston $2004^{178}$ & $14 C D$ & \\
\hline & Häuser $2006^{170}$ & $516 C D$ & \\
\hline & Häuser $2006^{171}$ & $446 C D$ & \\
\hline & Nachman $2009^{128}$ & 132 Newly diagnosed CD & \\
\hline & Nachman $2010^{163}$ & 53 Newly diagnosed CD & \\
\hline & Hopman $2009^{179}$ & $53 C D$ & \\
\hline & Tontini $2010^{180}$ & $43 C D$ & \\
\hline & Aksan 2015 & $205 C D$ & \\
\hline \multicolumn{4}{|l|}{ CD-specific scales } \\
\hline
\end{tabular}




\section{Table 3 Continued}

\begin{tabular}{|c|c|c|c|}
\hline \multicolumn{4}{|l|}{ Adult instruments } \\
\hline Instrument & Author & Participants & Instrument description \\
\hline \multirow[t]{7}{*}{ Celiac Disease Questionnaire ${ }^{30}$} & Häuser $2006^{170}$ & $516 C D$ & \multirow{7}{*}{$\begin{array}{l}\text { 28-Item self-report, 7-point Likert scale. Measures four domains: emotional and social problems, disease- } \\
\text { related worries and GI symptoms. }\end{array}$} \\
\hline & Zampieron $2011^{181}$ & $187 C D$ & \\
\hline & Ford $2012^{165}$ & $288 C D$ & \\
\hline & Marchese $2013^{182}$ & $171 \mathrm{CD}$ & \\
\hline & Sainsbury $2013^{155}$ & $189 C D$ & \\
\hline & Pouchot $2014^{183}$ & $211 C D$ & \\
\hline & Aksan 2015 & $205 C D$ & \\
\hline \multirow{9}{*}{$\begin{array}{l}\text { Celiac Disease Quality of Life } \\
\text { Survey }^{29}\end{array}$} & Mahadev $2016^{127}$ & $211 C D$ & \multirow{9}{*}{$\begin{array}{l}\text { 20-Item self-report, 5-point Likert scale. four subscales: limitations, dysphoria, health concerns and inadequate } \\
\text { treatment. }\end{array}$} \\
\hline & Zingone $2011^{184}$ & $230 \mathrm{CD}$ & \\
\hline & Casellas $2013^{185}$ & $298 C D$ & \\
\hline & Casellas $2015^{159}$ & $366 C D$ on $G F D>1$ year & \\
\hline & Lee $2016^{186}$ & $2138 C D$ & \\
\hline & $\begin{array}{l}\text { Rodriguez-Almagro } \\
2016^{187}\end{array}$ & $1230 \mathrm{CD}$ & \\
\hline & Russo $2017^{188}$ & $19 C D$ & \\
\hline & Castilhos $2015^{189}$ & $103 C D$ & \\
\hline & Dowd $2017^{190}$ & $220 C D$ & \\
\hline \multicolumn{4}{|l|}{ Fatigue scales } \\
\hline $\begin{array}{l}\text { The Chronic Fatigue Syndrome } \\
\text { Questionnaire }\end{array}$ & Siniscalchi $2005^{192}$ & $130 C D$ & 8-Item self-report for physical fatigue and five items for mental fatigue. The score ranges from 0 to 26 . \\
\hline The Fatigue Severity Scale ${ }^{193}$ & & & $\begin{array}{l}\text { 9-Item self-report (score range 1-7 according to patient' agreement) } \\
\text { The scores range from } 9 \text { to } 63 \text {. }\end{array}$ \\
\hline $\begin{array}{l}\text { Daily Fatigue Impact Scale } \\
\text { Questionnaire }\end{array}$ & Jordà $2010^{195}$ & $51 C D$ & $\begin{array}{l}\text { 8-Item self-report questionnaire, five alternative responses per item (from } 0=\text { no problem, to } \\
4=\text { extreme problem). }\end{array}$ \\
\hline \multicolumn{4}{|l|}{ Eating disorder scales } \\
\hline Binge Eating Staircases ${ }^{196}$ & Passananti $2013^{197}$ & $100 C D$ & $\begin{array}{l}\text { 16-Item self-report. Measures the behavioural aspects of binge eating, as well as feelings and thoughts } \\
\text { associated with binge eating. }\end{array}$ \\
\hline Eating Attitudes Test $26^{198}$ & Passananti $2013^{197}$ & $100 \mathrm{CD}$ & 26-Item self-report, multiple choice. Assesses diet-related disorders, bulimia and anxiety-related to food. \\
\hline \multirow[t]{3}{*}{ Eating Disorder Inventory $2^{199}$} & Passananti $2013^{197}$ & $100 C D$ & \multirow{3}{*}{$\begin{array}{l}\text { 91-Item self-report (range } 0-78 \text { ); } 11 \text { scales, eg, inadequacy, interceptive awareness, fear of maturity, } \\
\text { asceticism, impulsivity and social insecurity. }\end{array}$} \\
\hline & Wagner $2015^{200}$ & $259 \mathrm{CD}$ adolescents & \\
\hline & Karwautz $2008^{201}$ & $283 \mathrm{CD}$ adolescents & \\
\hline \multirow{2}{*}{$\begin{array}{l}\text { Eating Disorder Examination } \\
(\mathrm{EDE})^{202}\end{array}$} & Wagner $2015^{200}$ & $259 \mathrm{CD}$ adolescents & \multirow{2}{*}{$\begin{array}{l}\text { 45-60 min semi-structured interview ( } 28 \text {-day recall). Four subscales: restraint, eating concern, shape concern, } \\
\text { weight concern. }\end{array}$} \\
\hline & Karwautz $2008^{201}$ & $283 \mathrm{CD}$ adolescents & \\
\hline $\begin{array}{l}\text { Eating Disorder Examination } \\
\text { Questionnaire (EDE-Q) })^{203}\end{array}$ & Karwautz $2008^{201}$ & $283 \mathrm{CD}$ adolescents & 28-Item, self-report. Uses same subscales as the EDE interview. \\
\hline \multicolumn{4}{|l|}{ Sleep disorders scale } \\
\hline Pittsburgh Sleep Quality Index ${ }^{204}$ & Zingone $2010^{205}$ & $60 C D$ & $\begin{array}{l}19 \text { self-rated items ( } 15 \text { multiple choice and } 4 \text { write in) }+5 \text { questions rated by a bed partner or roommate (range } \\
0-57 \text { ). }\end{array}$ \\
\hline \multicolumn{4}{|l|}{ Paediatric scales } \\
\hline \multirow{2}{*}{$\begin{array}{l}\text { TNO-AZL Children's QOL } \\
\text { questionnaire (TACQOL) parent }{ }^{206} \\
\text { and child }{ }^{207} \text { report }\end{array}$} & Kolsteren $2001^{208}$ & $133 C D$ children & \multirow{2}{*}{$\begin{array}{l}\text { Generic-two forms for children and parents: The TACQOL comprises seven scales (range0-16): } \\
\text { Generic: Dutch Children TNO-AZL QOL Questionnaire } 25 \text { items with four. } \\
\text { Domains: emotional, social, familiar, and physical. }\end{array}$} \\
\hline & van Koppen $2009^{209}$ & $32 \mathrm{CD}$ children & \\
\hline DUX-25 210 & van Koppen $2009^{209}$ & $32 \mathrm{CD}$ children & (Ages 5-16) 25-item self-report with four domains: physical, emotional, social and home functioning. \\
\hline $\begin{array}{l}\text { Inventory of Life Quality in Children } \\
\text { and Adolescents } \\
\text { s }^{211}\end{array}$ & Wagner $2008^{212}$ & $365 \mathrm{CD}$ adolescents & $\begin{array}{l}\text { 9-Item self-rating questionnaire } \\
\text { Nine areas: school, family, social peer contacts, interests and leisure activities, physical health, psychological } \\
\text { health, overall QoL judgement and disease and therapy-associated burden. }\end{array}$ \\
\hline $\begin{array}{l}\text { Berner Subjective Well-being } \\
\text { Inventory }{ }^{213}\end{array}$ & Wagner $2008^{212}$ & $365 \mathrm{CD}$ adolescents & 39-Item self-report questionnaire, with 4-point and 6-point Likert scale questions. \\
\hline \multirow[t]{3}{*}{$\begin{array}{l}\text { PedsQL core: Paediatric Quality of } \\
\text { Life Measurement Inventory }\end{array}$} & Sud $2012^{215}$ & $\begin{array}{l}28 C D+\text { type } 1 \text { diabetes } \\
\text { children }\end{array}$ & \multirow[t]{3}{*}{$\begin{array}{l}\text { Four areas: physical functioning (eight items), emotional functioning (five items), social functioning (five items) } \\
\text { and school functioning (five items). }\end{array}$} \\
\hline & Biagetti $2015^{216}$ & $76 \mathrm{CD}$ children & \\
\hline & Sevinc $2016^{217}$ & $52 \mathrm{CD}$ children & \\
\hline WHOQOL-BREF ${ }^{218}$ & de Lorenzo $2012^{219}$ & $\begin{array}{l}33 C D \text { child/parent dyads } \\
\text { vs } 62 \text { control child/parent } \\
\text { dyads }\end{array}$ & $\begin{array}{l}\text { 26-Item self-report (parent), 5-point Likert scale. Six domains: Ioneliness, general health perception, physical } \\
\text { and psychological functioning, social and environmental. }\end{array}$ \\
\hline $\begin{array}{l}\text { Autoquestionnaire de l'Enfant Imagé } \\
\text {-AUQUEI (child form) }\end{array}$ & de Lorenzo $2012^{219}$ & $\begin{array}{l}33 C D \text { child/parent dyads } \\
\text { vs } 62 \text { control child/parent } \\
\text { dyads }\end{array}$ & $\begin{array}{l}\text { 26-Item self-report (child), explores familial and social relationships, physical activity, health, body functions } \\
\text { and temporary separation from the familial environment. }\end{array}$ \\
\hline \multirow[t]{2}{*}{ EuroQol-5D ${ }^{156}$} & Nordyke $2011^{221}$ & $\begin{array}{l}153 \text { screen-detected } C D \\
\text { children and } 66 \text { known } C D \\
\text { vs non-CD controls }\end{array}$ & \multirow[t]{2}{*}{$\begin{array}{l}\text { 5-Item self-report, 5-point Likert scale, plus a general health rating (scored on a } 20 \mathrm{~cm} \text { visual analogue scale) } \\
\text { (child friendly pilot and proxy used). }\end{array}$} \\
\hline & Nordyke $2013^{222}$ & 207 CD vs non-CD controls & \\
\hline DISABKIDS Chronic (short version) $)^{223}$ & Bystrom $2012^{224}$ & $160 \mathrm{CD}$ child/parent dyads & $\begin{array}{l}\text { 12-Item self-report Likert scale for ages 8-18 (additional available version for ages 4-7) mental, social and } \\
\text { physical domains. }\end{array}$ \\
\hline
\end{tabular}




\begin{tabular}{|c|c|c|c|}
\hline Continued & & & \\
\hline \multicolumn{4}{|l|}{ Adult instruments } \\
\hline Instrument & Author & Participants & Instrument description \\
\hline 12-Item Short Form Survey (SF-12) ${ }^{225}$ & Altobelli $2013^{226}$ & 140 CD children & $\begin{array}{l}\text { 12-Item questionnaire, eight domains: physical functioning, role-physical, bodily pain, general health, vitality, } \\
\text { social functioning, role-emotional and mental health. }\end{array}$ \\
\hline $\begin{array}{l}\text { Impact Scale of Childhood } \\
\text { Diseases }\end{array}$ & Di Filippo $2013^{228}$ & $45 C D$ children & $\begin{array}{l}\text { 30-Item self-report, four domains: impact of disease and treatment, impact on child development and } \\
\text { adjustment, impact on parents and impact on family. }\end{array}$ \\
\hline Kidscreen ${ }^{229}$ & Myleus $2014^{230}$ & $328 C D$ children & $\begin{array}{l}\text { 52-Item self-report, measures overall HRQoL along with } 10 \mathrm{HRQ} \text { oL subdomains capturing physical well-being, } \\
\text { psychological well-being, moods and emotions, self-perception, autonomy, parent relation and home life, } \\
\text { financial resources, social support and peers, school environment and social acceptance (bullying); 5-point } \\
\text { Likert scale. }\end{array}$ \\
\hline Children's Depression Inventory ${ }^{231}$ & Simsek $2015^{135}$ & $25 \mathrm{CD}$ children & $\begin{array}{l}\text { 27-Item, self-report, symptom-oriented scale } \\
\text { (ages 7-17). }\end{array}$ \\
\hline $\begin{array}{l}\text { General Purpose Health-Related } \\
\text { Quality of Life Questionnaire for } \\
\text { Children }\end{array}$ & Simsek $2015^{135}$ & $25 \mathrm{CD}$ children & $\begin{array}{l}\text { 40-Item, self-report, four domains: psychological well-being, social relationships, physical function and } \\
\text { everyday life activities. }\end{array}$ \\
\hline \multicolumn{4}{|l|}{ CD-specific (paediatric) scales } \\
\hline TACQOL-COE & Kolsteren $2001^{208}$ & $133 C D$ children & $\begin{array}{l}\text { CD-specific instrument (based on TACQOL) TACQOL-COE-DIET: } \\
\text { Five questions to address GFD. }\end{array}$ \\
\hline \multirow[t]{6}{*}{$\operatorname{CDDUX}^{233}$} & Van Koppen $2009^{209}$ & $32 \mathrm{CD}$ children & 12-Item questionnaire, three domains: communication, having $C D$ and diet. \\
\hline & Pico $2014^{234}$ & $118 C D$ child/parent dyads & \\
\hline & Torres $2016^{235}$ & $\begin{array}{l}214 C D \text { child/parent dyads } \\
\text { and } 52 C D \text { children }\end{array}$ & \\
\hline & Lins $2015^{236}$ & $33 \mathrm{CD}$ children & \\
\hline & Vriezinga $2016^{237}$ & $78 \mathrm{CD}$ children & \\
\hline & Meyer $2016^{238}$ & $34 \mathrm{CD}$ child/parent dyads & \\
\hline $\begin{array}{l}\text { Celiac Disease Paediatric Quality of } \\
\text { Life Scale }\end{array}$ & $\begin{array}{l}\text { Jordan } 2013^{239} \\
\text { (validation study) }\end{array}$ & $181 C D$ children & $\begin{array}{l}\text { 13-Item (ages 8-12) and 17-item (ages 13-18) scale. Home, school, social and self-esteem (also diet and } \\
\text { future in 13-18 tool). } \\
\text { Ages 8-18 only. }\end{array}$ \\
\hline
\end{tabular}

CDDUX, celiac disease DUX.

\section{DISCUSSION}

\section{Strengths and limitations}

In this review, a large number of authors reviewed the literature on treatment outcomes in coeliac trials to issue recommendations for future trials. Our research team was multidisciplinary and the treatment outcomes we have evaluated in the paper reflect the expert views of the authors.

We performed an extensive literature review of more than 10000 papers, and based our deliberations on personal experiences and expertise from our treatment of patients with CD with clinical trials and our research in CD. There are already a number of guidelines for reporting treatment outcome in CD. ${ }^{136}$ Hence, our paper is not meant to give authoritative advice on the study design, which is not yet possible because of the developing nature of the field, but to complement available literature with our expertise with a focus on how to measure response to non-GFD treatment.

$\mathrm{CD}$ is a lifelong disease in which the GFD is the only treatment option. However, we suspect that soon other alternative treatments will become commonplace.

Regulatory agencies are responsible for evaluating new therapies based on risks and benefits to patients in how they feel, function or survive. ${ }^{80}$ These aims are of intuitive value to patients and clinicians and sufficiently broad that they should form the foundation of any interventional clinical trial. Despite this, the precedent in many fields, including gastroenterology, has been the use of poorly validated outcomes of limited applicability to clinical practise. Although CD adversely impacts survival ${ }^{6137138}$ and function, ${ }^{139-143}$ these outcomes are generally not feasible to assess in clinical trials because of low prevalence and long latency. This leaves the options of measuring how patients feel-mainly using PROs, histology and serology-to assess changes in risk of future adverse events. Ideally, a treatment should result in improvement in more than one outcome measures (PROs, histology and serology), and that is possible using a coprimary end point. However, coprimary end points should be used with caution since they decrease study power and the number of patients is often limited.

There are currently several well-designed and partially validated PROs developed for CD that should be considered standards for trials in the future. Assessment of extent (degree) of enteropathy (intestinal architecture and IEL assessment) should be considered as a critical outcome in clinical trials of CD. However, it is recognised that technical limitations of duodenal biopsy as a reflection of overall small intestinal mucosal disease limit the potential value of histology as an end point. Development techniques that better evaluate enteropathy across the small intestine are applicable in clinical practise and relevant to patients.

Author affiliations

${ }^{1}$ Department of Medical Epidemiology and Biostatistics, Karolinska Institutet, Stockholm, Sweden

${ }^{2}$ Department of Pediatrics, Örebro University Hospital, Örebro, Sweden

${ }^{3}$ Coeliac Center at Department of Medicine and Surgery, Scuola Medica Salernitana,

University of Salerno, Salerno, Italy

${ }^{4}$ Celiac Disease Center at Columbia University, New York, USA

${ }^{5}$ Celiac Disease Research Center, Faculty of Medicine and Life Sciences, University of Tampere, Tampere, Finland

${ }^{6}$ Department of Internal Medicine, Tampere University Hospital, Tampere, Finland

${ }^{7}$ Coeliac Disease Centre, Heim Pál Children's Hospital, Budapest, Hungary

${ }^{8}$ Department of Paediatrics, Faculty of Medicine, University of Debrecen, Debrecen, Hungary

${ }^{9}$ Celiac Disease Research Center, Faculty of Medicine and Life Sciences, University of Tampere, Tampere, Finland

${ }^{10}$ Department of Paediatrics, Tampere University Hospital, Tampere, Finland

${ }^{11}$ The Mayo Clinic, Rochester, Minnesota, USA

${ }^{12}$ Institute of Clinical Medicine and K.G. Jebsen Coeliac Disease Research Centre, Faculty of Medicine, University of Oslo, Oslo, Norway

${ }^{13}$ Department of Gastroenterology, Oslo University Hospital, Oslo, Norway

${ }^{14}$ Science Center, Tampere University Hospital, Tampere, Finland

${ }^{15}$ Tampere Centre for Child Health Research, Faculty of Medicine and Life Sciences, University of Tampere, Tampere, Finland

${ }^{16}$ Institute for Mother and Child Health Bucharest, University of Medicine and

Pharmacy 'Carol Davila', Bucharest, Romania

${ }^{17}$ Tampere Centre for Child Health Research, University of Tampere, Tampere University Hospital, Tampere, Finland 
${ }^{18}$ Division of Pediatric Gastroenterology, Columbia University Medical Center, New York, USA

${ }^{19}$ Celiac Disease Center, Department of Medicine, Columbia University Medical Center, New York, USA

${ }^{20}$ Grupo IHP Pediatria, Sevilla, Spain

${ }^{21}$ Academic Unit of Gastroenterology, Royal Hallamshire Hospital, University of Sheffield, Sheffield, UK

${ }^{22}$ Celiac Center, University Medical Center, Johannes-Gutenberg University, Mainz, Germany

${ }^{23}$ Division of Gastroenterology, Beth Israel Deaconess Medical Center, Boston, Massachusetts, USA

${ }^{24}$ Coeliac UK, Buckinghamshire, UK

${ }^{25}$ Tampere Centre for Child Health Research, University of Tampere, Tampere University Hospital, Tampere, Finland

${ }^{26}$ Continuum Clinical, Northbrook, Illinois, USA

${ }^{27}$ Faculty of Health and Medicine, School of Medicine and Public Health, University of Newcastle, Newcastle, New South Wales, Australia

${ }^{28}$ Celiac Center, Beth Israel Deaconess Medical Center, Harvard Medical School, Boston, Massachusetts, USA

Contributors JFL and DL initiated the study. JFL coordinated the study and wrote the first draft, the text was then extensively revised by the coauthors. All authors contributed to the literature searches, contributed to the writing of the manuscript and approved the final version of the manuscript.

Funding JFL was supported by the Swedish Research Council (522-2A09-195) and the Swedish Society of Medicine while writing the draft of this paper. DS received research support from the German Research Foundation (DFG), the Ministry of Research and Development (BMBF) and the Leibniz Foundation. DSS received an educational grant from Biocard and Simtomax to undertake an investigator-led research study on point-of-care tests and an educational grant from Dr Schär (a gluten-free food manufacturer) to undertake an investigator-led research study on gluten sensitivity. KKa was supported by the Academy of Finland, the Competitive Research Funding of the Tampere University Hospital and The Sigrid Juselius Foundation. IRK-S was supported by the Hungarian Research Fund (Grant NKFI 120392). MJM was supported by the Competitive State Research Financing of the Tampere University Hospital (grant 9U038).

Competing interests PHRG: scientific advisory board of Alvine Pharmaceuticals, ImmunogenX and ImmusanT. JAM: serves on the advisory board of Celimmune, was a consultant to BioLineRx, GlaxoSmithKline (GSK), Genentech, UCB Biopharma and Glenmark Pharmaceuticals Ltd and is a consultant to ImunnosanT, Institute for Protein Design (PvP Biologics), Takeda Pharmaceutical Company, Ltd., Innovate Biopharmaceuticals, Inc., Intrexon, 2GPharma Inc., Boeringer-Ingelheim and ImmusanT. KEAL: ImmusanT, Regeneron and Alvine Pharmaceuticals. DSS: holds a patent and receives royalties for the TG2-antibody assay, has received an educational grant from Coeliac UK, Biocard, Simtomax and Dr Schär to undertake an investigator-led research study on CD and/or gluten sensitivity. NRR: clinical advisory board for ImmusanT. DAL: Medical Director for Takeda Pharmaceuticals AR-H: coauthor detecting gluten peptides in human fluids (Patent No. US 20170160288 A1), consultant for Vircell. IRK-S: patent on rapid coeliac antibody detection licensed by the University of Tampere to Labsystems Oy, Finland. MJM: serves on the Advisory Board of Celimmune, USA, ImmusanT, USA and Innovate Pharmaceuticals Inc, USA; is consultant to FinnMedi Oy, Finland and Jilab Oy, Finland via his own company Maki HealthTech Oy, Finland; is an inventor in the patent Methods and Means for Detecting Gluten-Induced Diseases, USA (Patent No. 7,361,480—USA, European Patent No. 1390753). The patent resulted in a commercial product from FinnMedi at the Tampere University Hospital and the University of Tampere, a coeliac disease point-of-care test, Biocard Celiac Test, licensed to Labsystems Diagnostics Oy (former AniBiotech Oy), Finland.

Provenance and peer review Not commissioned; externally peer reviewed.

Open access This is an open access article distributed in accordance with the Creative Commons Attribution Non Commercial (CC BY-NC 4.0) license, which permits others to distribute, remix, adapt, build upon this work non-commercially, and license their derivative works on different terms, provided the original work is properly cited and the use is non-commercial. See: http://creativecommons.org/ licenses/by-nc/4.0/

(c) Article author(s) (or their employer(s) unless otherwise stated in the text of the article) 2018. All rights reserved. No commercial use is permitted unless otherwise expressly granted.

\section{REFERENCES}

1 Lebwohl B, Ludvigsson JF, Green PH. Celiac disease and non-celiac gluten sensitivity. BMJ 2015;351:h4347

2 Ludvigsson JF, Michaelsson K, Ekbom A, et al. Coeliac disease and the risk of fractures - a general population-based cohort study. Aliment Pharmacol Ther 2007;25:273-85.
3 Elfström P, Granath F, Ekström Smedby K, et al. Risk of lymphoproliferative malignancy in relation to small intestinal histopathology among patients with celiac disease. J Nat/ Cancer Inst 2011;103:436-44.

4 Ilus T, Kaukinen K, Virta LJ, et al. Incidence of malignancies in diagnosed celiac patients: a population-based estimate. Am J Gastroenterol 2014;109:1471-7.

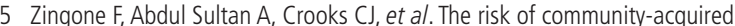
pneumonia among 9803 patients with coeliac disease compared to the general population: a cohort study. Aliment Pharmacol Ther 2016:44:57-67.

6 Ludvigsson JF, Montgomery SM, Ekbom A, et al. Small-intestinal histopathology and mortality risk in celiac disease. JAMA 2009;302:1171-8.

7 Ludvigsson JF, Leffler DA, Bai JC, et al. The Oslo definitions for coeliac disease and related terms. Gut 2013;62:43-52.

8 Mäki M, Mustalahti K, Kokkonen J, et al. Prevalence of Celiac disease among children in Finland. N Engl J Med 2003;348:2517-24.

9 Walker MM, Murray JA, Ronkainen J, et al. Detection of celiac disease and lymphocytic enteropathy by parallel serology and histopathology in a populationbased study. Gastroenterology 2010;139:112-9.

10 Lohi S, Mustalahti K, Kaukinen K, et al. Increasing prevalence of coeliac disease over time. Aliment Pharmacol Ther 2007;26:1217-25.

11 West J, Fleming KM, Tata LJ, et al. Incidence and prevalence of celiac disease and dermatitis herpetiformis in the UK over two decades: population-based study. Am J Gastroenterol 2014;109:757-68.

12 Zingone F, Swift GL, Card TR, et al. Psychological morbidity of celiac disease: A review of the literature. United European Gastroenterol J 2015:3:136-45.

13 Shah S, Akbari M, Vanga $R$, et al. Patient perception of treatment burden is high in celiac disease compared with other common conditions. Am J Gastroenterol 2014; 109:1304-11.

14 Lee AR, Ng DL, Zivin J, et al. Economic burden of a gluten-free diet. J Hum Nutr Diet 2007; 20:423-30

15 Singh J, Whelan K. Limited availability and higher cost of gluten-free foods. J Hum Nutr Diet 2011:24:479-86.

16 Burden M, Mooney PD, Blanshard RJ, et al. Cost and availability of gluten-free food in the UK: in store and online. Postgrad Med J 2015;91:622-6.

17 Sollid LM, Khosla C. Novel therapies for coeliac disease. J Intern Med 2011:269:604-13.

18 Wungjiranirun M, Kelly CP, Leffler DA. Current status of celiac disease drug development. Am J Gastroenterol 2016;111:779-86.

19 Aziz I, Evans KE, Papageorgiou V, et al. Are patients with coeliac disease seeking alternative therapies to a gluten-free diet? J Gastrointestin Liver Dis 2011:20:27-31.

20 Hindryckx P, Levesque BG, Holvoet T, et al. Disease activity indices in coeliac disease: systematic review and recommendations for clinical trials. Gut 2018:67:61-9.

21 Marsh MN. Gluten, major histocompatibility complex, and the small intestine. A molecular and immunobiologic approach to the spectrum of gluten sensitivity ('celiac sprue'). Gastroenterology 1992:102:330-54.

22 Oberhuber G, Granditsch G, Vogelsang H. The histopathology of coeliac disease: time for a standardized report scheme for pathologists. Eur J Gastroenterol Hepatol 1999;11:1185-94

23 Rostami K, Kerckhaert J, von Blomberg BM, et al. SAT and serology in adult coeliacs, seronegative coeliac disease seems a reality. Neth J Med 1998;53:15-19.

24 Villanacci V, Magazzù G, Pellegrino S, et al. Comparison of the marsh-oberhuber classification with a new grading system in identifying patients with latent celiac disease. Minerva Gastroenterol Dietol 2010;56:371-5.

25 Ensari A. Gluten-sensitive enteropathy (celiac disease): controversies in diagnosis and classification. Arch Pathol Lab Med 2010;134:826-36.

26 Taavela J, Koskinen O, Huhtala $\mathrm{H}$, et al. Validation of morphometric analyses of small-intestinal biopsy readouts in celiac disease. PLoS One 2013:8:e76163.

27 Leffler DA, Kelly CP, Green PH, et al. Larazotide acetate for persistent symptoms of celiac disease despite a gluten-free diet: a randomized controlled trial. Gastroenterology 2015;148:1311-9.

28 Adelman DC, Leffler D, Lebwohl B, et al. Celiac disease symptom frequency and severity using a disease-specific patient-reported outcome diary: observations from a psychometric validation study in 202 patients. Am J Gastro 2012;107:S603.

29 Dorn SD, Hernandez L, Minaya MT, et al. The development and validation of a new coeliac disease quality of life survey (CD-QOL). Aliment Pharmacol Ther 2010;31:666-75.

30 Häuser W, Gold J, Stallmach A, et al. Development and validation of the Celiac Disease Questionnaire (CDQ), a disease-specific health-related quality of life measure for adult patients with celiac disease. J Clin Gastroenterol 2007:41:157-66.

31 Leffler DA, Dennis M, Edwards George J, et al. A validated disease-specific symptom index for adults with celiac disease. Clin Gastroenterol Hepatol 2009;7:1328e1-1334.

32 Lee SK, Lo W, Memeo L, et al. Duodenal histology in patients with celiac disease after treatment with a gluten-free diet. Gastrointest Endosc 2003;57:187-91.

33 Tursi A, Brandimarte G, Giorgetti GM, et al. Endoscopic and histological findings in the duodenum of adults with celiac disease before and after changing to a glutenfree diet: a 2-year prospective study. Endoscopy 2006;38:702-7.

34 Cammarota G, Cuoco L, Cesaro P, et al. A highly accurate method for monitoring histological recovery in patients with celiac disease on a gluten-free diet using 
an endoscopic approach that avoids the need for biopsy: a double-center study. Endoscopy 2007;39:46-51.

35 Maiden L, Elliott T, McLaughlin SD, et al. A blinded pilot comparison of capsule endoscopy and small bowel histology in unresponsive celiac disease. Dig Dis SCi 2009;54:1280-3

36 Oxford Centre for Evidence-based Medicine. Levels of evidence. Oxford: Oxford Centre for Evidence-based Medicine, 2009.

37 Liberati A, Altman DG, Tetzlaff J, et al. The PRISMA statement for reporting systematic reviews and meta-analyses of studies that evaluate healthcare interventions: explanation and elaboration. BMJ 2009;339:b2700.

38 Rubio-Tapia A, Hill ID, Kelly CP, et al. ACG clinical guidelines: diagnosis and management of celiac disease. Am J Gastroenterol 2013;108:656-76.

39 Ludvigsson JF, Bai JC, Biagi F, et al. Diagnosis and management of adult coeliac disease: guidelines from the British Society of Gastroenterology. Gut 2014;63:1210-28

40 Husby S, Koletzko S, Korponay-Szabó IR, et al. European society for pediatric gastroenterology, hepatology, and nutrition guidelines for the diagnosis of coeliac disease. J Pediatr Gastroenterol Nutr 2012;54:136-60.

41 Corazza GR, Villanacci V. Coeliac disease. J Clin Pathol 2005:58:573-4.

42 Gottlieb K, Dawson J, Hussain F, et al. Development of drugs for celiac disease: review of endpoints for Phase 2 and 3 trials. Gastroenterol Rep 2015:3:91-102.

43 Babbin BA, Crawford K, Sitaraman SV. Malabsorption work-up: utility of small bowel biopsy. Clin Gastroenterol Hepatol 2006;4:1193-8.

44 Latorre M, Lagana SM, Freedberg DE, et al. Endoscopic biopsy technique in the diagnosis of celiac disease: one bite or two? Gastrointest Endosc 2015;81:1228-33.

45 Ravelli A, Villanacci V. Tricks of the trade: how to avoid histological pitfalls in celiac disease. Pathol Res Pract 2012;208:197-202.

46 Rostami K, Marsh MN, Johnson MW, et al. ROC-king onwards: intraepithelial lymphocyte counts, distribution \& role in coeliac disease mucosal interpretation. Gut 2017;66:2080-6.

47 Veress B, Franzén L, Bodin L, et al. Duodenal intraepithelial lymphocyte-count revisited. Scand J Gastroenterol 2004;39:138-44.

48 Järvinen TT, Kaukinen K, Laurila K, et al. Intraepithelial lymphocytes in celiac disease. Am J Gastroenterol 2003;98:1332-7.

49 Lonardi S, Villanacci V, Lorenzi L, et al. Anti-TCR gamma antibody in celiac disease: the value of count on formalin-fixed paraffin-embedded biopsies. Virchows Arch 2013:463:409-13.

50 Zanini B, Marullo M, Villanacci V, et al. Persistent intraepithelial lymphocytosis in celiac patients adhering to gluten-free diet is not abolished despite a gluten contamination elimination diet. Nutrients 2016;8:525

51 Korponay-Szabó IR, Halttunen T, Szalai Z, et al. In vivo targeting of intestinal and extraintestinal transglutaminase 2 by coeliac autoantibodies. Gut 2004;53:641-8.

52 Koskinen O, Collin P, Lindfors K, et al. Usefulness of small-bowel mucosal transglutaminase-2 specific autoantibody deposits in the diagnosis and follow-up of celiac disease. J Clin Gastroenterol 2010;44:483-8.

53 Gatti S, Rossi M, Alfonsi S, et al. Beyond the intestinal celiac mucosa: diagnostic role of anti-TG2 deposits, a systematic review. Front Med 2014;1:9.

54 Lähdeaho ML, Mäki M, Laurila K, et al. Small- bowel mucosal changes and antibody responses after low- and moderate-dose gluten challenge in celiac disease. BMC Gastroenterol 2011:11:129.

55 Arguelles-Grande C, Tennyson CA, Lewis SK, et al. Variability in small bowel histopathology reporting between different pathology practice settings: impact on the diagnosis of coeliac disease. J Clin Pathol 2012;65:242-7.

56 Picarelli A, Borghini R, Donato $G$, et al. Weaknesses of histological analysis in celiac disease diagnosis: new possible scenarios. Scand J Gastroenterol 2014;49:1-7.

57 Dixon MF, Genta RM, Yardley JH, et al. Classification and grading of gastritis. The updated Sydney system. International workshop on the histopathology of gastritis, Houston 1994. Am J Surg Pathol 1996;20:1161-81.

58 Malfertheiner $\mathrm{P}$, Megraud F, O'Morain CA, et al. Management of helicobacter pylori infection-the maastricht v/florence consensus report. Gut 2017;66:6-30.

59 Lebwohl B, Green PH, Genta RM. The coeliac stomach: gastritis in patients with coeliac disease. Aliment Pharmacol Ther 2015;42:180-7.

60 Verzegnassi F, Bua J, De Angelis P, et al. Eosinophilic oesophagitis and coeliac disease: is it just a casual association? Gut 2007;56:1029-30.

61 Trovato CM, Montuori M, Anania C, et al. Are ESPGHAN " biopsy-sparing" guidelines for celiac disease also suitable for asymptomatic patients? Am J Gastroenterol 2015;110:1485-9.

62 Ghazzawi Y, Rubio-Tapia A, Murray JA, et al. Mucosal healing in children with treated celiac disease. J Pediatr Gastroenterol Nutr 2014;59:229-31.

63 Leffler DA, Schuppan D. Update on serologic testing in celiac disease. Am J Gastroenterol 2010;105:2520-4.

64 Bai JC, Fried M, Corazza GR, et al. World gastroenterology organisation global guidelines on celiac disease. J Clin Gastroenterol 2013;47:121-6.

65 Reeves GE, Squance ML, Duggan AE, et al. Diagnostic accuracy of coeliac serological tests: a prospective study. Eur J Gastroenterol Hepatol 2006;18:493-501.

66 Naiyer AJ, Hernandez L, Ciaccio EJ, et al. Comparison of commercially available serologic kits for the detection of celiac disease. J Clin Gastroenterol 2009;43:225-32
67 Simon-Vecsei Z, Király R, Bagossi P, et al. A single conformational transglutaminase 2 epitope contributed by three domains is critical for celiac antibody binding and effects. Proc Natl Acad Sci U S A 2012;109:431-6.

68 Iversen R, Mysling S, Hnida K, et al. Activity-regulating structural changes and autoantibody epitopes in transglutaminase 2 assessed by hydrogen/deuterium exchange. Proc Natl Acad Sci U S A 2014:111:17146-51.

69 Kanchan K, Ergülen E, Király R, et al. Identification of a specific one amino acid change in recombinant human transglutaminase 2 that regulates its activity and calcium sensitivity. Biochem J 2013;455:261-72.

70 Alessio MG, Tonutti E, Brusca I, et al. Correlation between IgA tissue transglutaminase antibody ratio and histological finding in celiac disease. J Pediatr Gastroenterol Nutr 2012:55:44-9.

71 Taavela J, Kurppa K, Collin P, et al. Degree of damage to the small bowel and serum antibody titers correlate with clinical presentation of patients with celiac disease. Clin Gastroenterol Hepatol 2013;11:166-71.

72 Singh P, Kurray L, Agnihotri A, et al. Titers of anti-tissue transglutaminase antibody correlate well with severity of villous abnormalities in celiac disease. J Clin Gastroenterol 2015;49:212-7.

73 Pekki H, Kurppa K, Mäki M, et al. Predictors and significance of incomplete mucosal recovery in celiac disease after 1 year on a gluten-free diet. Am J Gastroenterol 2015:110:1078-85.

74 Silvester JA, Kurada S, Szwajcer A, et al. Tests for serum transglutaminase and endomysial antibodies do not detect most patients with celiac disease and persistent villous atrophy on gluten-free diets: a meta-analysis. Gastroenterology 2017:153:689-701.

75 Murray JA, Rubio-Tapia A, Van Dyke CT, et al. Mucosal atrophy in celiac disease: extent of involvement, correlation with clinical presentation, and response to treatment. Clin Gastroenterol Hepatol 2008;6:186-93.

76 Hopper AD, Hadjivassiliou M, Hurlstone DP, et al. What is the role of serologic testing in celiac disease? A prospective, biopsy-confirmed study with economic analysis. Clin Gastroenterol Hepatol 2008;6:314-20.

77 Leffler D, Schuppan D, Pallav K, et al. Kinetics of the histological, serological and symptomatic responses to gluten challenge in adults with coeliac disease. Gut 2013;62:996-1004.

78 Sarna VK, Skodje GI, Reims HM, et al. HLA-DQ: gluten tetramer test in blood gives better detection of coeliac patients than biopsy after 14-day gluten challenge. Gut 2017:gutjnl-2017-314461

79 Matysiak-Budnik T, Malamut G, de Serre NP, et al. Long-term follow-up of 61 coeliac patients diagnosed in childhood: evolution toward latency is possible on a normal diet. Gut 2007:56:1379-86.

80 Leffler D, Kupfer SS, Lebwohl B, et al. Development of celiac disease therapeutics: report of the third gastroenterology regulatory endpoints and advancement of therapeutics workshop. Gastroenterology 2016;151:407-11.

81 Forsberg G, Hernell O, Melgar S, et al. Paradoxical coexpression of proinflammatory and down-regulatory cytokines in intestinal T cells in childhood celiac disease. Gastroenterology 2002;123:667-78.

82 Brottveit M, Beitnes AC, Tollefsen S, et al. Mucosal cytokine response after shortterm gluten challenge in celiac disease and non-celiac gluten sensitivity. Am J Gastroenterol 2013;108:842-50.

83 Kontakou M, Przemioslo RT, Sturgess RP, et al. Cytokine mRNA expression in the mucosa of treated coeliac patients after wheat peptide challenge. Gu 1995:37:52-7.

84 Goel G, King T, Daveson AJ, et al. Epitope-specific immunotherapy targeting CD4positive T cells in coeliac disease: two randomised, double-blind, placebo-controlled phase 1 studies. Lancet Gastroenterol Hepatol 2017:2:479-93.

85 Ontiveros N, Tye-Din JA, Hardy MY, et al. Ex-vivo whole blood secretion of interferon (IFN)- $\gamma$ and IFN- $\gamma$-inducible protein-10 measured by enzyme-linked immunosorbent assay are as sensitive as IFN- $\gamma$ enzyme-linked immunospot for the detection of gluten-reactive T cells in human leucocyte antigen (HLA)-DQ2·5(+) -associated coeliac disease. Clin Exp Immunol 2014;175:305-15.

86 Manavalan JS, Hernandez L, Shah JG, et al. Serum cytokine elevations in celiac disease: association with disease presentation. Hum Immunol 2010;71:50-7.

87 Lundin KE, Scott H, Hansen T, et al. Gliadin-specific, HLA-DQ(alpha 1*0501, beta $1{ }^{*} 0201$ ) restricted $T$ cells isolated from the small intestinal mucosa of celiac disease patients. J Exp Med 1993;178:187-96.

88 Lundin $\mathrm{KE}$, Scott $\mathrm{H}$, Fausa $\mathrm{O}$, et al. T cells from the small intestinal mucosa of a DR4, DQ7/DR4, DQ8 celiac disease patient preferentially recognize gliadin when presented by DQ8. Hum Immunol 1994;41:285-91.

89 van de Wal Y, Kooy YM, van Veelen PA, et al. Small intestinal T cells of celiac disease patients recognize a natural pepsin fragment of gliadin. Proc Natl Acad Sci U SA 1998:95:10050-4.

90 Jabri B, Sollid LM. T cells in celiac disease. J Immunol 2017:198:3005-14.

91 Anderson RP, Degano P, Godkin AJ, et al. In vivo antigen challenge in celiac disease identifies a single transglutaminase-modified peptide as the dominant A-gliadin T-cell epitope. Nat Med 2000;6:337-42.

92 Anderson RP, van Heel DA, Tye-Din JA, et al. T cells in peripheral blood after gluten challenge in coeliac disease. Gut 2005;54:1217-23. 
93 Quarsten H, McAdam SN, Jensen T, et al. Staining of celiac disease-relevant T cells by peptide-DQ2 multimers. J Immuno/ 2001;167:4861-8.

94 Ráki M, Fallang LE, Brottveit M, et al. Tetramer visualization of gut-homing glutenspecific T cells in the peripheral blood of celiac disease patients. Proc Nat/ Acad Sci U SA 2007; 104:2831-6.

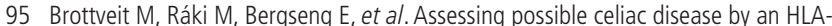
DQ2-gliadin tetramer test. Am J Gastroenterol 2011;106:1318-24.

96 Christophersen A, Ráki M, Bergseng E, et al. Tetramer-visualized gluten-specific CD4+ T cells in blood as a potential diagnostic marker for coeliac disease without oral gluten challenge. United European Gastroenterol J 2014;2:268-78.

97 Dahal-Koirala S, Risnes LF, Christophersen A, et al. TCR sequencing of single cells reactive to DQ2.5-glia-?]2 and DQ2.5-glia-??2 reveals clonal expansion and epitopespecific V-gene usage. Mucosal Immunol 2016;9:587-96.

98 Garber ME, Saldanha A, Parker JS, et al. A B-cell gene signature correlates with the extent of gluten-induced intestinal injury in celiac disease. Cell Mol Gastroenterol Hepatol 2017:4:1-17

99 Lähdeaho ML, Kaukinen K, Laurila K, et al. Glutenase ALV003 attenuates gluten-induced mucosal injury in patients with celiac disease. Gastroenterology 2014:146:1649-58.

100 Moreno ML, Rodríguez-Herrera A, Sousa C, et al. Biomarkers to monitor gluten-free diet compliance in celiac patients. Nutrients 2017;9:46.

101 Shan L, Qiao SW, Arentz-Hansen H, et al. Identification and analysis of multivalent proteolytically resistant peptides from gluten: implications for celiac sprue. J Proteome Res 2005:4:1732-41.

102 Shan L, Molberg $\varnothing$, Parrot I, et al. Structural basis for gluten intolerance in celiac sprue. Science 2002:297:2275-9.

103 Comino I, Real A, Vivas S, et al. Monitoring of gluten-free diet compliance in celiac patients by assessment of gliadin 33-mer equivalent epitopes in feces. Am J Clin Nutr 2012;95:670-7.

104 Comino I, Fernández-Bañares F, Esteve M, et al. Fecal gluten peptides reveal limitations of serological tests and food questionnaires for monitoring gluten-free diet in celiac disease patients. Am J Gastroenterol 2016;111:1456-65.

105 Moreno ML, Cebolla Á, Muñoz-Suano A, et al. Detection of gluten immunogenic peptides in the urine of patients with coeliac disease reveals transgressions in the gluten-free diet and incomplete mucosal healing. Gut 2017:66:250-7.

106 Sulic AM, Kurppa K, Rauhavirta T, et al. Transglutaminase as a therapeutic target for celiac disease. Expert Opin Ther Targets 2015;19:335-48.

107 Guidance for industry and FDA staff qualification process for drug development tools. US: U.S. Department of Health and Human Services FaDA, Center for Drug Evaluation and Research, 2014

108 Riaz MS, Atreja A. Personalized technologies in chronic gastrointestinal disorders: self-monitoring and remote sensor technologies. Clin Gastroenterol Hepatol 2016:14:1697-705.

109 Claims GfIP-ROMUiMPDTSL. US: U.S. Department of Health and Human Services FaDA, Center for Drug Evaluation and Research, Center for Biologics Evaluation and Research, Health CfDaR, 2009

110 Kelly CP, Green PH, Murray JA, et al. Larazotide acetate in patients with coeliac disease undergoing a gluten challenge: a randomised placebo-controlled study. Aliment Pharmacol Ther 2013;37:252-62.

111 Lohiniemi S, Mäki M, Kaukinen K, et al. Gastrointestinal symptoms rating scale in coeliac disease patients on wheat starch-based gluten-free diets. Scand J Gastroenterol 2000;35:947-9.

112 Murray JA, Kelly CP, Green PHR, et al. No difference between latiglutenase and placebo in reducing villous atrophy or improving symptoms in patients with symptomatic celiac disease. Gastroenterology 2017;152:787-98.

113 Crocker H, Jenkinson C, Churchman D, et al. The Coeliac Disease Assessment Questionnaire (Cdaq): development of a patient-reported outcome measure. Value in Health 2016;19:A595.

114 Zanini B, Baschè R, Ferraresi A, et al. Randomised clinical study: gluten challenge induces symptom recurrence in only a minority of patients who meet clinical criteria for non-coeliac gluten sensitivity. Aliment Pharmacol Ther 2015:42:968-76.

115 Hallert C, Grännö C, Grant C, et al. Quality of life of adult coeliac patients treated for 10 years. Scand I Gastroenterol 1998:33:977-8.

116 Kurppa K, Paavola A, Collin P, et al. Benefits of a gluten-free diet for asymptomatic patients with serologic markers of celiac disease. Gastroenterology 2014;147:610-7.

117 Svedlund J, Sjödin I, Dotevall G. GSRS--a clinical rating scale for gastrointestinal symptoms in patients with irritable bowel syndrome and peptic ulcer disease. Dig Dis Sci 1988;33:129-34.

118 Hendrickx GF, Somers K, Vandenplas Y. Lane-Hamilton syndrome: case report and review of the literature. Eur J Pediatr 2011;170:1597-602.

119 Silvester JA, Graff LA, Rigaux L, et al. Symptomatic suspected gluten exposure is common among patients with coeliac disease on a gluten-free diet. Aliment Pharmacol Ther 2016:44:612-9.

120 Mahadev S, Simpson S, Lebwohl B, et al. Is dietitian use associated with celiac disease outcomes? Nutrients 2013;5:1585-94

121 Crocker HPM, Jenkinson C. The Coeliac Disease Assessment Questionnaire (CDAQ). 2016 .
122 Lahiff C, Safaie P, Awais A, et al. The Crohn's disease activity index (CDAI) is similarly elevated in patients with Crohn's disease and in patients with irritable bowel syndrome. Aliment Pharmacol Ther 2013;37:786-94.

123 Mahadev S, Murray JA, Wu TT, et al. Factors associated with villus atrophy in symptomatic coeliac disease patients on a gluten-free diet. Aliment Pharmacol Ther 2017:45:1084-93

124 Fritscher-Ravens A, Schuppan D, Ellrichmann M, et al. Confocal endomicroscopy shows food-associated changes in the intestinal mucosa of patients with irritable bowel syndrome. Gastroenterology 2014;147:1012-20.

125 Zanini B, Caselani F, Magni A, et al. Celiac disease with mild enteropathy is not mild disease. Clin Gastroenterol Hepatol 2013;11:253-8.

126 Lanzini A, Lanzarotto F, Villanacci V, et al. Complete recovery of intestinal mucosa occurs very rarely in adult coeliac patients despite adherence to gluten-free diet. Aliment Pharmacol Ther 2009;29:1299-308.

127 Mahadev S, Gardner R, Lewis SK, et al. Quality of life in screen-detected celiac disease patients in the United States. J Clin Gastroenterol 2016;50:393-7.

128 Nachman F, Mauriño E, Vázquez H, et al. Quality of life in celiac disease patients: prospective analysis on the importance of clinical severity at diagnosis and the impact of treatment. Dig Liver Dis 2009;41:15-25.

129 Burger JPW, de Brouwer B, IntHout J, et al. Systematic review with meta-analysis: dietary adherence influences normalization of health-related quality of life in coeliac disease. Clin Nutr 2017:36:399-406.

130 Paavola A, Kurppa K, Ukkola A, et al. Gastrointestinal symptoms and quality of life in screen-detected celiac disease. Dig Liver Dis 2012;44:814-8.

131 Mustalahti K, Lohiniemi S, Collin P, et al. Gluten-free diet and quality of life in patients with screen-detected celiac disease. Eff Clin Pract 2002;5:105-13.

132 Ukkola A, Mäki M, Kurppa K, et al. Diet improves perception of health and wellbeing in symptomatic, but not asymptomatic, patients with celiac disease. Clin Gastroenterol Hepatol 2011;9:118-23.

133 Fera T, Cascio B, Angelini G, et al. Affective disorders and quality of life in adult coeliac disease patients on a gluten-free diet. Eur J Gastroenterol Hepatol 2003; 15:1287-92.

134 Addolorato G, Capristo E, Ghittoni G, et al. Anxiety but not depression decrease in coeliac patients after one-year gluten-free diet: a longitudinal study. Scand J Gastroenterol 2001:36:502-6.

135 Simsek S, Baysoy G, Gencoglan S, et al. Effects of gluten-free diet on quality of life and depression in children with celiac disease. J Pediatr Gastroenterol Nutr 2015;61:303-6

136 Moher D, Hopewell S, Schulz KF, et al. Consort 2010 explanation and elaboration: updated guidelines for reporting parallel group randomised trials. BMJ 2010;340:C869.

137 Tio M, Cox MR, Eslick GD. Meta-analysis: coeliac disease and the risk of all-cause mortality, any malignancy and lymphoid malignancy. Aliment Pharmacol Ther 2012:35:540-51.

138 Biagi F, Corazza GR. Mortality in celiac disease. Nat Rev Gastroenterol Hepatol 2010:7:158-62

139 Heikkilä K, Pearce J, Mäki M, et al. Celiac disease and bone fractures: a systematic review and meta-analysis. J Clin Endocrinol Metab 2015;100:25-34.

140 Lebwohl B, Michaëlsson K, Green PH, et al. Persistent mucosal damage and risk of fracture in celiac disease. J Clin Endocrinol Metab 2014:99:609-16.

141 Lichtwark IT, Newnham ED, Robinson SR, et al. Cognitive impairment in coeliac disease improves on a gluten-free diet and correlates with histological and serological indices of disease severity. Aliment Pharmacol Ther 2014;40:160-70.

142 Hadjivassiliou M, Rao DG, Grinewald RA, et al. Neurological dysfunction in coeliac disease and non-coeliac gluten sensitivity. Am J Gastroenterol 2016;111:561-7

143 Catassi C, Fasano A. Celiac disease as a cause of growth retardation in childhood. Curr Opin Pediatr 2004;16:445-9.

144 Tack GJ, van de Water JM, Bruins MJ, et al. Consumption of gluten with glutendegrading enzyme by celiac patients: a pilot-study. World J Gastroenterol 2013:19:5837-47

145 Catassi C, Fabiani E, lacono G, et al. A prospective, double-blind, placebo-controlled trial to establish a safe gluten threshold for patients with celiac disease. Am J Clin Nutr 2007:85:160-6.

146 Holm K, Mäki M, Vuolteenaho N, et al. Oats in the treatment of childhood coeliac disease: a 2-year controlled trial and a long-term clinical follow-up study. Aliment Pharmacol Ther 2006;23:1463-72.

147 Catassi C, Rossini M, Rätsch IM, et al. Dose dependent effects of protracted ingestion of small amounts of gliadin in coeliac disease children: a clinical and jejunal morphometric study. Gut 1993;34:1515-9.

148 Leffler DA, Kelly CP, Abdallah HZ, et al. A randomized, double-blind study of larazotide acetate to prevent the activation of celiac disease during gluten challenge. Am J Gastroenterol 2012;107:1554-62.

149 Zung WW. A self-rating depression scale. Arch Gen Psychiatry 1965;12:63-70.

150 Ciacci C, D'Agate C, De Rosa A, et al. Self-rated quality of life in celiac disease. Dig Dis Sci 2003;48:2216-20.

151 Quintana JM, Cabriada J, López de Tejada I, et al. Translation and validation of the gastrointestinal Quality of Life Index (GIQLI). Rev Esp Enferm Dig 2001;93:693-706. 
152 Casellas F, Rodrigo L, Vivancos JL, et al. Factors that impact health-related quality of life in adults with celiac disease: a multicenter study. World I Gastroenterol 2008; 14:46-52.

153 Carver CS. You want to measure coping but your protocol's too long: consider the brief COPE. Int J Behav Med 1997;4:92-100.

154 Smith MM, Goodfellow L. The relationship between quality of life and coping strategies of adults with celiac disease adhering to a gluten-free diet. Gastroenterol Nurs 2011:34:460-8.

155 Sainsbury K, Mullan B, Sharpe L. Reduced quality of life in coeliac disease is more strongly associated with depression than gastrointestinal symptoms. J Psychosom Res 2013;75:135-41.

156 Brooks RG, Rabin R, De Charro F. The measurement and valuation of health status using EQ-5D: a European perspective: evidence from the EuroQol BIOMED Research Programme. Dordrchet; Boston: Kluwer Academic Pub, 2003.

157 Gray AM, Papanicolas IN. Impact of symptoms on quality of life before and after diagnosis of coeliac disease: results from a UK population survey. BMC Health Serv Res 2010;10:105

158 Norström F, Lindholm L, Sandström O, et al. Delay to celiac disease diagnosis and its implications for health-related quality of life. BMC Gastroenterol 2011;11:118.

159 Casellas F, Rodrigo L, Lucendo AJ, et al. Benefit on health-related quality of life of adherence to gluten-free diet in adult patients with celiac disease. Rev Esp Enferm Dig 2015; 107:196-201.

160 Ramírez-Cervantes KL, Remes-Troche JM, Del Pilar Milke-García M, et al. Characteristics and factors related to quality of life in Mexican Mestizo patients with celiac disease. BMC Gastroenterol 2015;15:4

161 Upton J. Beck Depression Inventory (BDI). In: Gellman MD, Turner JR, eds. Encyclopedia of behavioral medicine. New York, NY: Springer New York, 2013:178-9.

162 Borghini R, Di Tola M, Salvi E, et al. Impact of gluten-free diet on quality of life in celiac patients. Acta Gastroenterol Belg 2016;79:447-53.

163 Nachman F, del Campo MP, González A, et al. Long-term deterioration of quality of life in adult patients with celiac disease is associated with treatment noncompliance. Dig Liver Dis 2010;42:685-91.

164 Dupuy H. et al The Psychological General Wellbeing (PGWB) Index. In: Wenger N, Mattson M, Furberg C, Elinson J, . eds. Assessment of quality of life in clinical trials of cardiovascular therapies:170-83.

165 Ford S, Howard R, Oyebode J. Psychosocial aspects of coeliac disease: a crosssectional survey of a UK population. Br J Health Psychol 2012;17:743-57.

166 Peräaho M, Kaukinen K, Mustalahti K, et al. Effect of an oats-containing gluten-free diet on symptoms and quality of life in coeliac disease. A randomized study. Scand J Gastroenterol 2004:39:27-31.

167 Viljamaa M, Collin P, Huhtala H, et al. Is coeliac disease screening in risk groups justified? A fourteen-year follow-up with special focus on compliance and quality of life. Aliment Pharmacol Ther 2005;22:317-24.

168 Paarlahti P, Kurppa K, Ukkola A, et al. Predictors of persistent symptoms and reduced quality of life in treated coeliac disease patients: a large cross-sectional study. BMC Gastroenterol 2013;13:75.

169 Zigmond AS, Snaith RP. The hospital anxiety and depression scale. Acta Psychiatr Scand 1983:67:361-70.

170 Häuser W, Stallmach A, Caspary WF, et al. Predictors of reduced healthrelated quality of life in adults with coeliac disease. Aliment Pharmacol Ther 2007:25:569-78

171 Häuser W, Gold J, Stein J, et al. Health-related quality of life in adult coeliac disease in Germany: results of a national survey. Eur J Gastroenterol Hepatol 2006;18:747-54

172 Barratt SM, Leeds JS, Robinson K, et al. Reflux and irritable bowel syndrome are negative predictors of quality of life in coeliac disease and inflammatory bowel disease. Eur J Gastroenterol Hepatol 2011:23:159-65.

173 Barratt SM, Leeds JS, Sanders DS. Quality of life in coeliac disease is determined by perceived degree of difficulty adhering to a gluten-free diet, not the level of dietary adherence ultimately achieved. J Gastrointestin Liver Dis 2011;20:241-5.

174 Ware JE, Sherbourne CD. The MOS 36-item short-form health survey (SF-36). I. Conceptual framework and item selection. Med Care 1992;30:473-83.

175 Bakker SF, Pouwer F, Tushuizen ME, et al. Compromised quality of life in patients with both Type 1 diabetes mellitus and coeliac disease. Diabet Med 2013;30:835-9.

176 Usai P, Minerba L, Marini B, et al. Case control study on health-related quality of life in adult coeliac disease. Dig Liver Dis 2002;34:547-52.

177 Usai P, Manca R, Cuomo R, et al. Effect of gluten-free diet and co-morbidity of irritable bowel syndrome-type symptoms on health-related quality of life in adult coeliac patients. Dig Liver Dis 2007;39:824-8.

178 Johnston SD, Rodgers C, Watson RG. Quality of life in screen-detected and typical coeliac disease and the effect of excluding dietary gluten. Eur J Gastroenterol Hepatol 2004;16:1281-6

179 Hopman EG, Koopman HM, Wit JM, et al. Dietary compliance and health-related quality of life in patients with coeliac disease. Eur J Gastroenterol Hepatol 2009;21:1056-61.
180 Tontini GE, Rondonotti E, Saladino V, et al. Impact of gluten withdrawal on health-related quality of life in celiac subjects: an observational case-control study. Digestion 2010;82:221-8.

181 Zampieron A, Daicampi C, Martin A, et al. Quality of life in adult celiac disease in a mountain area of northeast Italy. Gastroenterol Nurs 2011;34:313-9.

182 Marchese A, Klersy C, Biagi F, et al. Quality of life in coeliac patients: Italian validation of a coeliac questionnaire. Eur J Intern Med 2013;24:87-91.

183 Pouchot J, Despujol C, Malamut G, et al. Validation of a French version of the quality of life "celiac disease questionnaire". PLoS One 2014;9:e96346.

184 Zingone F, lavarone A, Tortora $\mathrm{R}$, et al. The Italian translation of the celiac diseasespecific quality of life scale in celiac patients on gluten free diet. Dig Liver Dis 2013:45:115-8.

185 Casellas F, Rodrigo L, Molina-Infante J, et al. Transcultural adaptation and validation of the Celiac Disease Quality of Life (CD-QOL) Survey, a specific questionnaire to measure quality of life in patients with celiac disease. Rev Esp Enferm Dig 2013; 105:585-93.

186 Lee AR, Wolf R, Contento I, et al. Coeliac disease: the association between quality of life and social support network participation. J Hum Nutr Diet 2016;29:383-90.

187 Rodríguez Almagro J, Hernández Martínez A, Lucendo AJ, et al. Health-related quality of life and determinant factors in celiac disease. A population-based analysis of adult patients in Spain. Rev Esp Enferm Dig 2016;108:181-9.

188 Russo F, Chimienti G, Clemente C, et al. A possible role for ghrelin, leptin, brain-derived neurotrophic factor and docosahexaenoic acid in reducing the quality of life of coeliac disease patients following a gluten-free diet. Eur J Nutr 2017;56:807-18.

189 Castilhos AC, Gonçalves BC, Silva MM, et al. Quality of life evaluation in celiac patients from southern Brazil. Arq Gastroenterol 2015;52:171-5.

190 Dowd AJ, Jung ME. Self-compassion directly and indirectly predicts dietary adherence and quality of life among adults with celiac disease. Appetite 2017;113:293-300.

191 Wessely S, Powell R. Fatigue syndromes: a comparison of chronic "postviral" fatigue with neuromuscular and affective disorders. J Neurol Neurosurg Psychiatry 1989:52:940-8

192 Siniscalchi M, lovino $P_{\text {, Tortora }}$, et al. Fatigue in adult coeliac disease. Aliment Pharmacol Ther 2005;22:489-94.

193 Krupp LB, LaRocca NG, Muir-Nash J, et al. The fatigue severity scale. Application to patients with multiple sclerosis and systemic lupus erythematosus. Arch Neurol 1989;46:1121-3.

194 Fisk JD, Doble SE. Construction and validation of a fatigue impact scale for daily administration (D-FIS). Qual Life Res 2002:11:263-72.

195 Jordá FC, López Vivancos J. Fatigue as a determinant of health in patients with celiac disease. J Clin Gastroenterol 2010:44:423-7.

196 Gormally J, Black S, Daston S, et al. The assessment of binge eating severity among obese persons. Addict Behav 1982;7:47-55.

197 Passananti V Siniscalchi M, Zingone F, et al. Prevalence of eating disorders in adults with celiac disease. Gastroenterol Res Pract 2013;2013:1-7.

198 Garner DM, Olmsted MP, Bohr Y, et al. The eating attitudes test: psychometric features and clinical correlates. Psychol Med 1982;12:871-8.

199 Garner DM, Olmstead MP, Polivy J. Development and validation of a multidimensional eating disorder inventory for anorexia nervosa and bulimia. Int $\mathrm{J}$ Eat Disord 1983;2:15-34.

200 Wagner G, Zeiler M, Berger G, et al. Eating disorders in adolescents with celiac disease: influence of personality characteristics and coping. Eur Eat Disord Rev 2015:23:361-70

201 Karwautz A, Wagner G, Berger G, et al. Eating pathology in adolescents with celiac disease. Psychosomatics 2008:49:399-406.

202 Fairburn CG. Cognitive behavior therapy and eating disorders. New York, NY: Guilford Press, 2008

203 Luce KH, Crowther JH, Pole M. Eating disorder examination questionnaire (EDE-Q) norms for undergraduate women. Int J Eat Disord 2008:41:273-6.

204 Buysse DJ, Reynolds CF, Monk TH, et al. The pittsburgh sleep quality index: a new instrument for psychiatric practice and research. Psychiatry Res 1989;28:193-213.

205 Zingone F, Siniscalchi M, Capone P, et al. The quality of sleep in patients with coeliac disease. Aliment Pharmacol Ther 2010;32:1031-6.

206 Vogels T, Verrips GH, Verloove-Vanhorick SP, et al. Measuring health-related quality of life in children: the development of the TACQOL parent form. Qual Life Res 1998;7:457-65.

207 Kamphuis R, Theunissen N, Witb J. Short communication health-related quality of life measure for children-the TACQOL. J App/ Therapeut 1997;1:357-60.

208 Kolsteren MM, Koopman HM, Schalekamp G, et al. Health-related quality of life in children with celiac disease.J Pediatr 2001:138:593-5.

209 van Koppen EJ, Schweizer JJ, Csizmadia CG, et al. Long-term health and quality-oflife consequences of mass screening for childhood celiac disease: a 10-year followup study. Pediatrics 2009;123:e582-588

210 Koopman H, Theunissen N, Vogels A, et al. The DUC-25: a short-form questionnaire for measuring health related quality of life of children with a chronic illness. Quality of Life Research 1998:619-19.

211 Mattejat $F_{\text {, }}$ Remschmidt $H$. The inventory of life quality in children and adolescents (ILC). Z Kinder-Jugendpsychiatrie 1998;26:183-96. 
212 Wagner G, Berger G, Sinnreich U, et al. Quality of life in adolescents with treated coeliac disease: influence of compliance and age at diagnosis. J Pediatr Gastroenterol Nutr 2008;47:555-61.

213 Grob A, Lüthi R, Kaiser FG, et al. Berner fragebogen zum wohlbefinden jugendlicher (BFW). Diagnostica 1991;37:66-75.

214 Varni JW, Seid M, Rode CA. The PedsQL: measurement model for the pediatric quality of life inventory. Med Care 1999;37:126-39.

215 Sud S, Marcon M, Assor E, et al. Quality of life in children with diabetes and celiac disease: minimal impact of the 'double diagnosis'. Pediatr Diabetes 2012;13:163-9.

216 Biagetti C, Gesuita R, Gatti S, et al. Quality of life in children with celiac disease: a paediatric cross-sectional study. Dig Liver Dis 2015;47:927-32.

217 Sevinç E, Çetin FH, Coşkun BD. Psychopathology, quality of life, and related factors in children with celiac disease. J Pediatr 2017;93:267-73.

218 Anon. Development of the World Health Organization WHOQOL-BREF quality of life assessment. The WHOQOL Group. Psychol Med 1998;28:551-8.

219 de Lorenzo CM, Xikota JC, Wayhs MC, et al. Evaluation of the quality of life of children with celiac disease and their parents: a case-control study. Qual Life Res 2012;21:77-85.

220 Manificat S, Dazord A, Cochat P, et al. [Evaluation of the quality of life in pediatrics: how to collect the point of view of children]. Arch Pediatr 1997;4:1238-46.

221 Nordyke K, Norström F, Lindholm L, et al. Health-related quality-of-life in children with coeliac disease, measured prior to receiving their diagnosis through screening. J Med Screen 2011;18:187-92.

222 Nordyke K, Norström F, Lindholm L, et al. Health-related quality of life in adolescents with screening-detected celiac disease, before and one year after diagnosis and initiation of gluten-free diet, a prospective nested case-referent study. BMC Public Health 2013;13:142.

223 Baars RM, Atherton Cl, Koopman HM, et al. The European DISABKIDS project: development of seven condition-specific modules to measure health related quality of life in children and adolescents. Health Qual Life Outcomes 2005;3:70.

224 Byström IM, Hollén E, Fälth-Magnusson $\mathrm{K}$, et al. Health-related quality of life in children and adolescents with celiac disease: from the perspectives of children and parents. Gastroenterol Res Pract 2012;2012:1-6.

225 Turner-Bowker D, Hogue SJ. Short form 12 health survey (sf-12). Michalos AC, ed. Encyclopedia of quality of life and well-being research. Dordrecht: Springer Netherlands, 2014:5954-7.
226 Altobelli E, Paduano R, Gentile T, et al. Health-related quality of life in children and adolescents with celiac disease: survey of a population from central Italy. Health Qual Life Outcomes 2013;11:204.

227 Hoare P, Russell M. The quality of life of children with chronic epilepsy and their families: preliminary findings with a new assessment measure. Dev Med Child Neurol 1995:37:689-96.

228 Di Filippo T, Orlando MF, Concialdi G, et al. The quality of life in developing age children with celiac disease. Minerva Pediatr 2013:65:599-608.

229 Ravens-Sieberer U, Gosch A, Rajmil L, et al. KIDSCREEN-52 quality-of-life measure for children and adolescents. Expert Rev Pharmacoecon Outcomes Res 2005;5:353-64.

230 Myléus A, Petersen S, Carlsson A, et al. Health-related quality of life is not impaired in children with undetected as well as diagnosed celiac disease: a large population based cross-sectional study. BMC Public Health 2014;14:425.

231 Kovacs M. The Children's Depression, Inventory (CDI). Psychopharmacol Bull 1985;21:995-8

232 Eser $\mathrm{E}$, Yüksel $\mathrm{H}$, Baydur $\mathrm{H}$, et al. [The psychometric properties of the new Turkish generic health-related quality of life questionnaire for children (Kid-KINDL)]. Turk Psikiyatri Derg 2008;19:409-17.

233 van Doorn RK, Winkler LM, Zwinderman KH, et al. CDDUX: a disease-specific health-related quality-of-life questionnaire for children with celiac disease. J Pediatr Gastroenterol Nutr 2008;47:147-52.

234 Pico M, Spirito MF. Implementation of a health-related quality of life questionnaire for children and adolescents with celiac disease. Arch Argent Pediatr 2014;112:19-25

235 Torres JB, Román E, Cilleruelo M, et al. Health-related quality of life in spanish children with coeliac disease. J Pediatr Gastroenterol Nutr 2016:62:603-8.

236 Lins MTC, Tassitano RM, Brandt KG, et al. Translation, cultural adaptation, and validation of the celiac disease DUX (CDDUX). J Pediatr 2015;91:448-54

237 Vriezinga SL, Farih N, van der Meulen-de Jong AE, et al. Comparison of patients' and doctors'reports on health-related quality of life in celiac disease. J Pediatr Gastroenterol Nutr 2017;64:737-41.

238 Meyer S, Rosenblum S. Children with celiac disease: health-related quality of life and leisure participation. Am J Occup Ther 2016;70:7006220010p1.

239 Jordan NE, Li Y, Magrini D, et al. Development and validation of a celiac disease quality of life instrument for North American children. J Pediatr Gastroenterol Nutr 2013;57:477-86. 